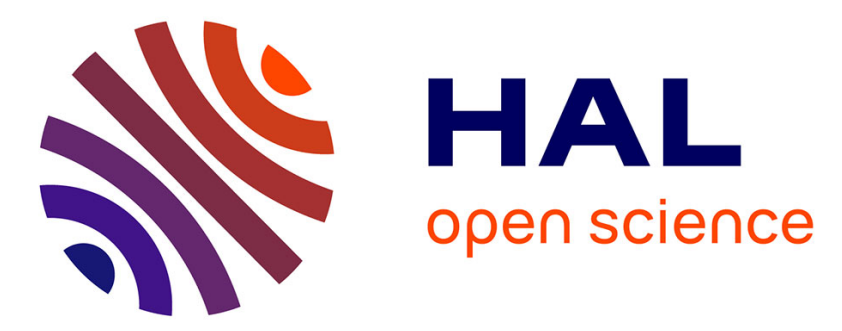

\title{
Approach to ferrocenyl-podophyllotoxin analogs and their evaluation as anti-tumor agents
}

Matthieu Beauperin, Dilan Polat, Fares Roudesly, Siden Top, Anne Vessières, Julie Oble, Gérard Jaouen, Giovanni Poli

\section{- To cite this version:}

Matthieu Beauperin, Dilan Polat, Fares Roudesly, Siden Top, Anne Vessières, et al.. Approach to ferrocenyl-podophyllotoxin analogs and their evaluation as anti-tumor agents. Journal of Organometallic Chemistry, 2017, 839, pp.83-90. 10.1016/j.jorganchem.2017.02.005 . hal-01480734

\section{HAL Id: hal-01480734 \\ https://hal.science/hal-01480734}

Submitted on 7 Mar 2017

HAL is a multi-disciplinary open access archive for the deposit and dissemination of scientific research documents, whether they are published or not. The documents may come from teaching and research institutions in France or abroad, or from public or private research centers.
L'archive ouverte pluridisciplinaire HAL, est destinée au dépôt et à la diffusion de documents scientifiques de niveau recherche, publiés ou non, émanant des établissements d'enseignement et de recherche français ou étrangers, des laboratoires publics ou privés. 


\title{
Approach to Ferrocenyl-Podophyllotoxin Analogs and their Evaluation as Anti-Tumor Agents
}

Matthieu Beaupérin, Dilan Polat, Fares Roudesly, Siden Top, Anne Vessières, Julie Oble,* Gérard Jaouen,* and Giovanni Poli*

Sorbonne Universités, UPMC Univ Paris 06, CNRS, Institut Parisien de Chimie Moléculaire (IPCM), UMR 8232, 4, place Jussieu, 75005 Paris, France

Corresponding authors E-mails:

julie.oble@upmc.fr

gerard.jaouen@chimie-paristech.fr

giovanni.poli@upmc.fr

\begin{abstract}
Podophyllotoxin is a natural product endowed of a high antimitotic activity and a high affinity for tubulin. Its action results in the cessation of cell division, inducing cell death. However, its high toxicity restrains its use as drug. To overcome this drawback, several chemical modifications of the native podophyllotoxin have been made. However, to date, no reports have so far been directed toward incorporation of a metallocene moiety. The search for new organometallic drugs is a central field in drug discovery, including the domain of cancer therapy. In particular, metallocenyl moieties are known to increase or decrease, depending on the degree of conjugation in the organometallic motif, the selectivity of drugs toward cancer cells. The conjugate organometallic compound reduces the damage of healthy tissues, yet permitting the selective desired antimitotic and cytotoxic effects of the active principle. We report here the synthesis of ferrocene-containing podophyllotoxin analogs and preliminary antiproliferative tests.
\end{abstract}




\section{Keywords}

antitumor agent

bioorganometallic chemistry

ferrocene

multi-step synthesis

palladium

podophyllotoxin

\section{Introduction}

In the family of cyclolignans, podophyllotoxin (PPT), a pentacyclic aryl-tetralin lignan isolated from the roots and rhizomes of the American Mayapple (Podophyllum Peltatum) [1] (Figure 1, left), has attracted much attention as it has shown various biological activities among which an interesting antiproliferative effect. This antineoplastic activity arises from inhibition of tubulin polymerization [2], a cytosolic protein required for the formation of the mitotic spindle. However, PPT exhibits a high toxicity and serious side effects like nausea, diarrhea, vomiting and damage to healthy tissue. Accordingly, its use is currently restricted to local treatments [3]. To overcome these drawbacks, several structure modification of podophyllotoxin have been performed on rings $\mathrm{C}$ (particularly the $\mathrm{C}-4$ position), $\mathrm{D}$ and $\mathrm{E}$, in view of obtaining more efficient and less toxic anticancer agents [4]. In particular, the two semi-synthetic derivatives, etoposide and teniposide [5] (Figure 1, right), have emerged, and are now widely used drugs for chemotherapies in lung cancer, lymphomas and genital tumors [6]. Intriguingly enough, unlike their parent compound, these derivatives are not tubulin inhibitors, acting on topoisomerase II. Structure activity relationship (SAR) studies suggest that topoisomerase II inhibition activity is (among other requisite features) associated to the presence of a free 4'-hydroxy group [3a]. However, etoposide is associated with some issues such as drug resistance and poor bioavailability. Furthermore, picropodophyllin (PPP) (Figure 1, left), the C-2 epimer of PPT, although showing no activity against either tubulin or topoisomerase, displays inhibitory activity against tyrosine phosphorylation of Insulin-like Growth Factor 1 receptor (IGF-1R) [7], which plays a crucial role in the transformation, growth, and survival of malignant cells. 


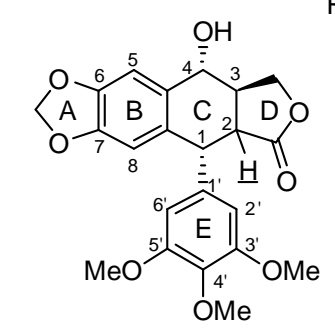

$\underline{\mathrm{H}}$ up: podophyllotoxin (PPT) $\underline{\underline{H}}$ down: picropodophyllin (PPP)

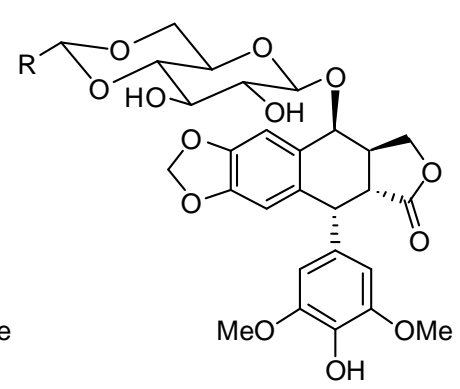

$\mathrm{R}=\mathrm{Me}$, etoposide

$\mathrm{R}=2$-thienyl, teniposide

Figure 1. Podophyllotoxin, picropophyllin, etoposide and teniposide structures.

Due to the severe toxic effects of podophyllotoxin and its derivatives, the discovery of more potent and/or less toxic analogs of this family is highly desirable. Most of the PPT analogs have been prepared from the native molecule by functionalization of the 4-hydroxy group [8]. As a consequence, modifications of ring $\mathrm{E}$ have been to date only scarcely explored [9]. A modern strategy towards the modulation of biologically active products consists in the incorporation of an organometallic motif into the drug [10,11]. Although organometallic compounds where used in therapy as early as the beginning of the $20^{\text {th }}$ century, this research field remained unexplored until 1996, when ferrocifen, a ferrocenyl analogue of tamoxifen, was reported, showing a high antiproliferative effect against two breast cancer cell lines: MCF-7 and MDA-MB-231 [12]. The mechanism of action of ferrocifen on MCF-7 cells seems to be partly analogous to that of tamoxifen, i.e. an antagonist effect on $\alpha$-type oestrogen receptors $(\mathrm{ER} \alpha)$. Yet, MDA-MB-231 cells, lacking $\mathrm{ER} \alpha$, show resistance to tamoxifen and a strong antiproliferative effect with ferrocifens, which suggests that ferrocifen and tamoxifen here act through different ways. Further studies have shown that the ferrocenyl moiety, by virtue of its reversible redox behavior, induced oxidative stress in the cell, catalyzing production of reactive oxygen species (ROS) [13]. Since that breakthrough, other pharmaceuticals were modified in a similar manner, giving rise to new bioactive organometallic compounds [14]. An example of the above strategy is ferroquine, an innovative antimalarial drug, currently at Phase II clinical trial at Sanofi-Aventis [15]. Due to their peculiar properties, such as increased lipophilicity and bulkiness with respect to the original drugs, these new conjugates allow targeting of different sites in the biological medium. In line with the above concept, we envisioned to prepare ferrocenyl podophyllotoxin analogs, either via hemisynthesis, by simply esterifying the hydroxyl group at C-4 with the 
ferroceny moiety (1) (Figure 2, left), or by incorporating the organometallic sandwich in place of ring $\mathrm{E}$ in a structure of type 2 (Figure 2, right).

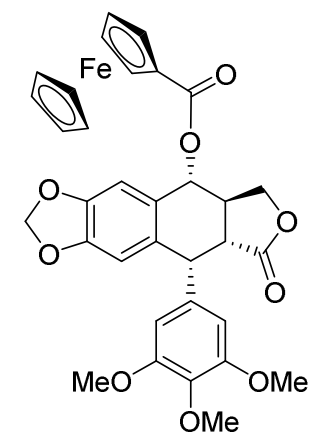

O-ferrocenylpodophyllotoxin 1<smiles>[R]OC(=O)C1CC(O)c2cc3c(cc2C1c1ccccc1)OCO3</smiles>

ferrocenylpodophyllotoxin analog 2

Figure 2. Targeted ferrocenyl analogs of podophyllotoxin.

\section{Results and discussion}

Derivative 1 was straightforwardly obtained in $60 \%$ yield from native podophyllotoxin by treatment with ferrocenoyl chloride [16], $\mathrm{Et}_{3} \mathrm{~N}$, and catalytic amount of DMAP (Scheme 1).

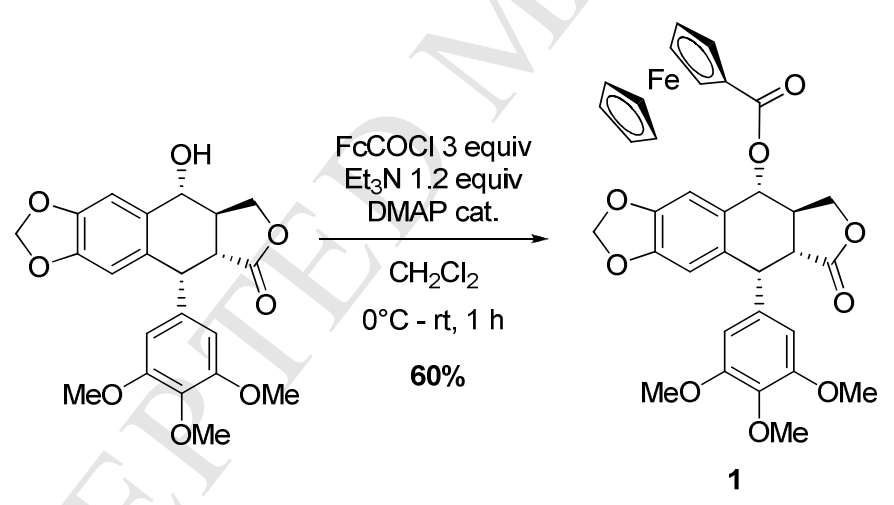

Scheme 1. Esterification of native PPT with ferrocenoyl chloride.

The strategy to targets such as $\mathbf{2}$ is more complex and requires a multistep synthesis. Accordingly, we decided to exploit a method we developed a few years ago [17] that gives access to the $\gamma$-oxo-ester key fragment $\mathbf{A}$ [18] (Scheme 2). This latter can be reached from the allylated $\beta$-dicarbonyl $\mathbf{B}$ via an intramolecular 6-exo Mizoroki-Heck coupling followed by alkene cleavage. $\mathbf{B}$ can result from a $\beta$-dicarbonyl derivative by allylation and alkylation with a ferrocenyl benzhydrol [19] such as $\mathbf{C}$, which can in turn derive from piperonal and ferrocene. In particular, we reasoned that the benzhydrylation could be best achieved using 
conditions favoring a $S_{N} 1$ mechanism,[20] analogously to the benzhydrylation of active methlylenes pioneered by us some years ago [21]. Furthermore, $\mathrm{S}_{\mathrm{N}} 1$-type nucleophilic substitutions on ferrocenyl derivatives are known to take place via iron assistance with retention of configuration [Error! Bookmark not defined.a-c]. As a consequence, control of the absolute configuration of the stereogenic center at the benzylic position might be a further bonus associated to this bioorganometallic approach. However, initially we focused our efforts only on the synthesis of racemic targets of type 2 lacking the lactone (D ring).

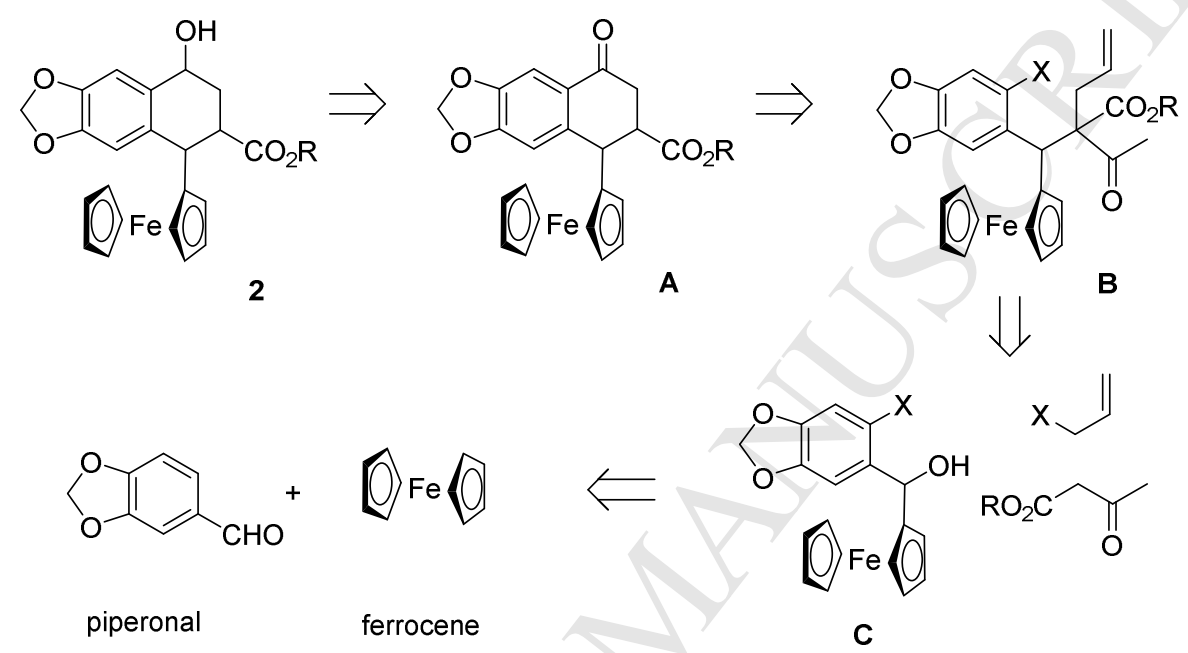

Scheme 2. Retrosynthetic approach to the ferrocenyl analog of podophyllotoxin 2.

Benzhydrylic alcohol $\mathbf{C}$ was obtained via two alternative approaches from commercially available 6-bromopiperonal 3, namely, either an oxidation / Friedel-Crafts acylation / reduction sequence (Scheme 3, top) or a direct condensation with ferrocenyl lithium (Scheme 3, down). The former synthesis started with a Pinnick-type oxidation of aldehyde $\mathbf{3}$ to give the corresponding carboxylic acid 3' (85\% y) by treatment with sodium chlorite in the presence of phosphoric acid [22]. After standard formation the corresponding acid chloride, FriedelCrafts acylation with ferrocene gave the diaryl ketone 3". Finally, $\mathrm{LiAlH}_{4}$ reduction gave alcohol C (47\% y). This sequence suffered from low yields, including generation of some debrominated alcohol C' during the last reductive step [23]. The second, more straightforward, approach gave alcohol $\mathbf{C}$ in one step by reaction between ferrocenyl lithium [24], and aldehyde 3 (44\% y). Although the latter approach is the one recommended, the former route may be reconsidered for a future enantiopure synthesis [25]. 


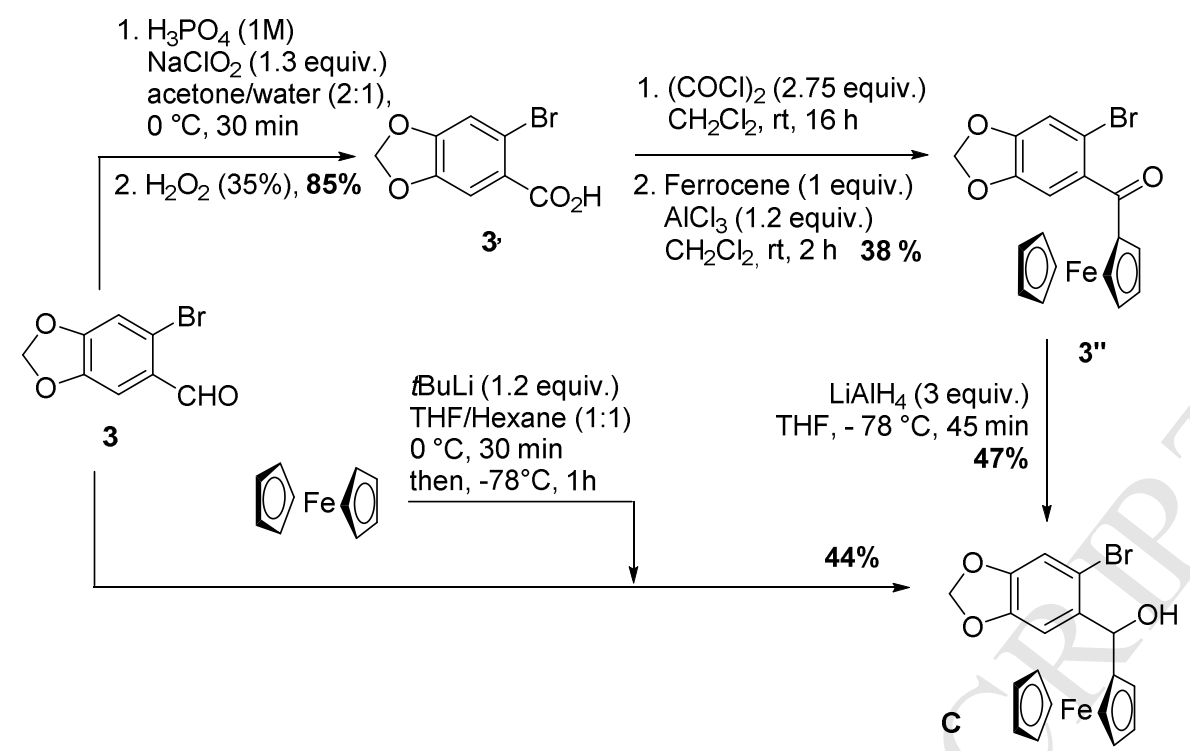

Scheme 3. Synthesis of o-bromo-sesamyl ferrocenyl alcohol C.

Substitution of alcohol $\mathbf{C}$ with $\beta$-dicarbonyl derivatives was then tackled. The acid promoted alkylation of benzhydrols is known to proceed via a $\mathrm{S}_{\mathrm{N}} 1$ mechanism [Error! Bookmark not defined.], the corresponding carbenium ion being highly stabilized by the two aromatic rings. Indeed, after a brief experimentation, we found that reaction between ethyl acetoacetate and alcohol $\mathbf{C}$ in the presence of catalytic $p \mathrm{TsOH}$ (5 mol\%) in refluxing $\mathrm{CH}_{2} \mathrm{Cl}_{2}$ was the best choice, affording the expected keto-ester 4 (75\% y) (Scheme 4). Other combinations using malonates instead of acetoacetates and Lewis acids (LA) or Brønsted acids (HA) other than $p \mathrm{TsOH}$ gave either lower yields or no reaction at all.[26] The subsequent allylation of 4 turned out to be troublesome. Standard conditions of Pd-catalyzed conditions [allyl acetate (2.5 equiv), $\mathrm{Pd}(\mathrm{OAc})_{2}(10 \mathrm{~mol} \%)$, dppe (20 mol\%), $\mathrm{NaH}$ (1.3 equiv)] gave back mainly unreacted starting material and only minor amounts of the desired adduct. A more classical allylation of the sodium enolate of $\mathbf{4}$ with allyl iodide gave more promising results, which could be improved when working in the presence of the 15-C-5 crown ether. In this case, the allylated product 5 could be obtained in up to $50 \%$ yield, although the reaction was not easily reproducible. The lack of reactivity of $\mathbf{4}$ may be due to steric hindrance of the ferrocenyl moiety. 

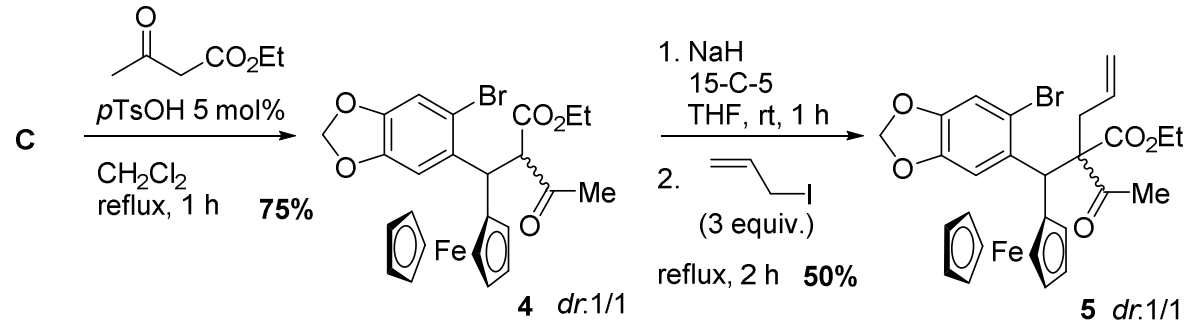

Scheme 4. Alkylation of benzydryl alcohol $\mathbf{C}$ and subsequent allylation of the resulting $\beta$ dicarbonyl derivative 4.

In light of the difficulties to allylate intermediate 4, we decided to perform the alkylation from the "pre-allylated" $\beta$-keto-ester 6 [27]. Such a variant would render the synthesis more convergent with respect to the previous plan, though requiring a challenging benzhydrylation with formation of a quaternary-center. In the event, use of the same acidic conditions as previously used to form $\mathbf{4}$, gave the targeted compound $\mathbf{5}$ in $35 \%$ yield, the main product being the symmetric ether 7 (50\% y) (Scheme 5, conditions a). This result suggests that under these conditions, unionized benzhydrol competes with the enol of 6 in the addition to the transient carbenium ion. Although under HA or LA catalysis the symmetric ether is in principle susceptible to give back the corresponding carbenium ion [21, 28], we were not able to exploit this prospective equilibrium to obtain an alternative access to 5. C-C bond formation via the Mitsunobu methodology is possible, provided that the $p \mathrm{Ka}$ of the Cpronucleophile is sufficiently low [29], and variants of the original [DEAD / TPP] system have been developed [30] to this purpose. For example, Tsunoda and co-workers [30a] used 1,1'-(azodicarbonyl)dipiperidine (ADDP) / tributylphosphine system to promote the reaction between diethyl malonate and benzylic alcohol. Under these conditions, $\mathbf{5}$ was obtained in a $35 \%$ yield after 3 days at room temperature (Scheme 5, conditions b). Although this result appeared promising, it still did not compare favorably with the previous strategies. Finally, we found that conversion of $\mathbf{C}$ into the corresponding chloride, followed by in situ treatment with the sodium enolate of $\mathbf{6}$ gave the desired 5 in $65 \%$ yield (Scheme 5, conditions c). Importantly, during chloride formation, $\mathrm{HCl}$ scavenging with 2,6-lutidine was necessary to inhibit formation of dimer 7. 


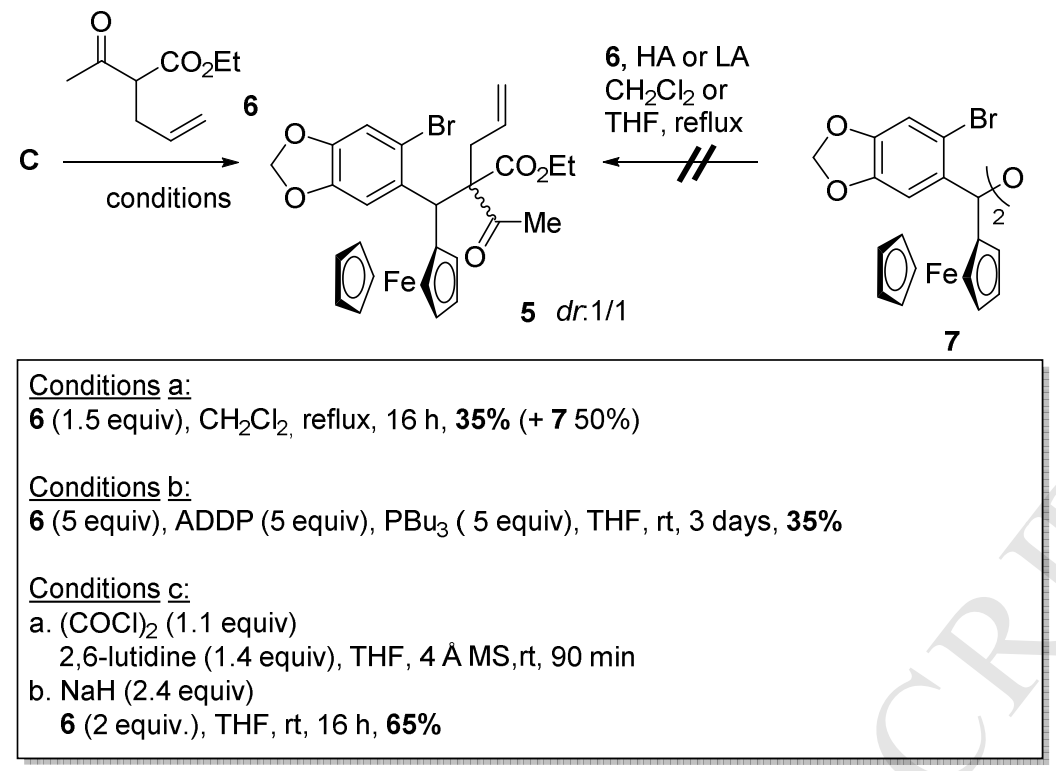

Scheme 5. Alkylation of benzhydryl alcohol $\mathbf{C}$ with the allylated $\beta$-dicarbonyl 6: three approaches compared.

Intramolecular palladium-catalyzed Mizoroki-Heck cyclization was next studied. The reaction proceeded satisfactorily under classical conditions [17] $\left[\mathrm{Pd}(\mathrm{OAc})_{2}(10 \mathrm{~mol} \%)\right.$, dppe (20 mol\%), $\mathrm{K}_{2} \mathrm{CO}_{3}$ (2equiv), DMF, $130^{\circ} \mathrm{C}$ ], providing the exocyclic alkene 8 in $84 \%$ yield (Scheme 6). The following planned retro-Claisen reaction was achieved straightforwardly by treatment with EtONa in a refluxing EtOH/THF, which gave the expected ester 9 in $95 \%$ yield [31]. Conversion of the methylidene into the key $\gamma$-oxo-ester $\mathbf{A}$ was then easily accomplished in $60 \%$ overall yield via osmium-catalyzed cis-dihydroxylation of $\mathbf{9}$ followed by $\mathrm{NaIO}_{4}$ cleavage [32]. The acid form of the $\gamma$-oxo-ester derivative $\mathbf{A}$, lacking the ferrocenyl tail, has already been identified as an advanced precursor to podophyllotoxin by Kende and coworkers,[18] who were able to obtain picropodophyllone by treatment with formaldehyde and $\mathrm{NaOH}$ [33]. Unfortunately, all attempts to further functionalize intermediate $\mathbf{A}$, so as to add ring $\mathrm{D}$, met with failure. Nevertheless, this study enabled us to have in hand a novel molecule incorporating rings $\mathrm{A}, \mathrm{B}$, and $\mathrm{C}$ of podophyllotoxin and carrying a ferrocenyl moiety in place of ring E. Accordingly, $\mathbf{A}(\mathrm{R}=\mathrm{Et})$ was directly submitted to $\mathrm{NaBH}_{4}$ reduction [34], and the resulting alcohol $2(\mathrm{R}=\mathrm{Et})$ was sent for antiproliferative tests. 


\section{ACCEPTED MANUSCRIPT}
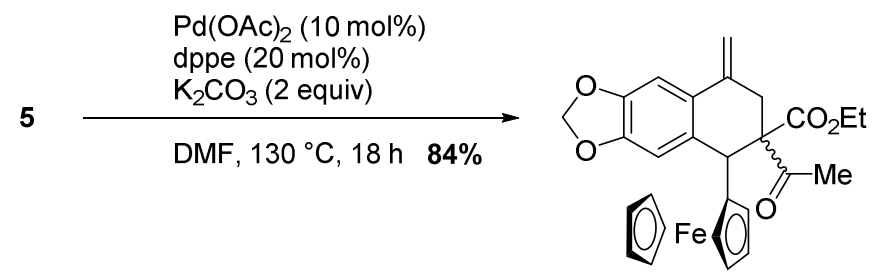

$8 d r: 1.5 / 1$<smiles>CCOC(=O)[C@H]1C[C@](O)(CO)c2cc3c(cc2C1c1ccccc1)OCO3</smiles>

EtONa (1.1 equiv)

THF, reflux, $3 \mathrm{~h}, 95 \%$

$\mathrm{NaIO}_{4}$ (2.4 equiv) acetone $/ \mathrm{H}_{2} \mathrm{O}$, rt, $3 \mathrm{~h}$, $60 \%$ (over the 2 steps)<smiles>CCOC(=O)C1CC(=O)c2cc3c(cc2C1c1ccccc1)OCO3</smiles>

$A(\mathrm{R}=\mathrm{Et})$ dr.1.8/1 (cis/trans)

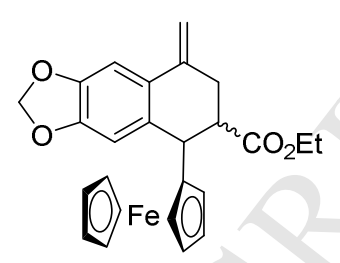

$9 d r .1 .8 / 1$

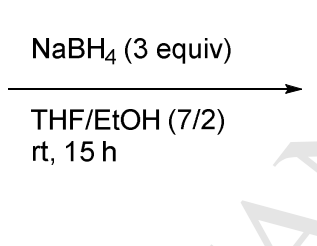

THF/EtOH $(7 / 2)$

rt, $15 \mathrm{~h}$

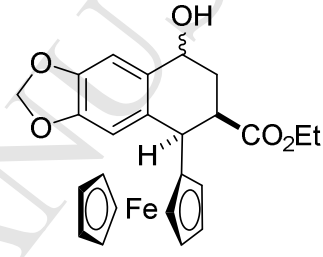

$2(\mathrm{R}=\mathrm{Et})$ dr. $3 / 1$

Scheme 6. Construction of ring $\mathbf{C}$ and subsequent conversion into the targeted analogue.

Three samples have been tested on the two breast cancer cell lines: MCF-7 and MDA-MB231. Podophyllotoxin was tested as a reference, together with the O-ferrocenylpodophyllotoxin (OFCP) analog 1 and the alcohol $2(\mathrm{R}=\mathrm{Et})$ (Table 1).[35]

Table 1. $\mathrm{IC}_{50}$ values of compounds on the hormone-dependent (MCF-7) and hormoneindependent (MDA-MB-231) breast cancer cell lines

\begin{tabular}{lll}
\hline Compound & $\begin{array}{l}\mathrm{MCF}-7 \\
\left(\mathrm{IC}_{50} \mu \mathrm{M}\right)^{*}\end{array}$ & $\begin{array}{l}\mathrm{MDA}-\mathrm{MB}-231 \\
\left(\mathrm{IC}_{50} \mu \mathrm{M}\right)^{*}\end{array}$ \\
\hline Podophyllotoxin & $0.01 \pm 0.00$ & $0.01 \pm 0.00$ \\
OFCP 1 & $0.93 \pm 0.07$ & $0.43 \pm 0.03$ \\
"Alcohol 2 (R = Et)" & $39.75 \pm 2.00$ & $27.6 \pm 2.40$ \\
\hline
\end{tabular}

*Mean of two separate experiments 
Podophyllotoxin was found very active against both cancer cell lines $\left(\mathrm{IC}_{50} 0.01 \mu \mathrm{M}\right)$ proving its high cytotoxicity. By incorporating a ferrocenyl moiety into the molecule, the cytotoxicity is reduced; the $\mathrm{IC}_{50}$ values of OFCP 1 were $0.93 \mu \mathrm{M}$ for MCF-7 and $0.43 \mu \mathrm{M}$ for MDA-MB231 which is in the average values generally found for ferrocifens. These values are still satisfactory and may justify further studies. The reduced cytotoxicity of $\mathbf{1}$ as compared to the organic precursor is reminiscent to the result obtained with ferrocenyl modification of the extremely toxic illudin [36]. An organometallic modification decreases its toxicity on fibroblasts and increases its selectivity on cancer cells. Compound $\mathbf{1}$ could be easier to use than podophyllotoxin. By contrast to $\mathbf{1}$, the alcohol $\mathbf{2}$ shows high $\mathrm{IC}_{50}$ proving that $\mathbf{2}$ is much less active than $\mathbf{1}$. It is interesting to note that the organic moiety of $\mathbf{2}$ is different from podophyllotoxin molecule.

In the multitargeting ferrocifen series the cytotoxicity is mainly due so far to the redox primer \{ferrocenyl-ene-phenol\} producing ROS and able to delocalize the initial radical cation and generate electrophilic quinone methides at the mitochondrial level [14a]. When the ferrocenyl phenol species are unconjugated the anticancer effect decreases [37]. In the present case the organometallic motifs are different from this arrangement but this type of oxidative effect can be invoked to explain the results. The above redox ferrocifen motif is not unique in order to modulate the anticancer effects in a structure bearing a ferrocenyl group. Indeed, the recent literature reports other primers related to our original concept, producing similar effects in which the central electronic conduit in adjacent position to a ferrocenyl species is a naphtyl group or an ene- 2,5-piperazinedione unit [38]. Unveiling such an effect expands our original discovery and may be of interest for future developments of organometallic antitumor species.

\section{Conclusion}

In this study we report the synthesis of two new podophyllotoxin analogs incorporating a ferrocenyl moiety and the preliminary antiproliferative tests of these conjugates on two breast cancer lines. While the former compound has been straightforwardly obtained by esterification between podophyllotoxin and ferrocenecarboxylic acid, the latter molecule, incorporating rings $\mathrm{A}, \mathrm{B}$ and $\mathrm{C}$ of podophyllotoxin and carrying the ferrocenyl appendage in place of ring $\mathrm{E}$ of podophyllotoxin, required a 6-step synthesis starting from 6bromopiperonal and ferrocene. Key steps in the synthesis were a challenging benzhydrylation generating a quaternary center, and an intramolecular Mizoroki-Heck reaction, which formed ring $\mathrm{C}$ of the target molecule. Such original structures have been discussed in terms of the importance of ferrocenyl conjugated motifs to generate antiproliferative effects. 


\section{Experimental section}

Reactions were carried out under argon atmosphere. All reagents were used as obtained from commercial suppliers. Dichloromethane and DMF were dried on a Braun purification system MB SPS-800. THF was distilled over sodium/benzophenone under nitrogen atmosphere. Thin layer chromatography was performed on Merck 60 F254 silica gel and revealed with an ultraviolet lamp $(\lambda=254 \mathrm{~nm})$ and a staining reagent $\left(\mathrm{KMnO}_{4}\right.$, vanillin or para-anisaldehyde). Merck Geduran SI 60 silica gel $(40-63 \mu \mathrm{m})$ was used for flash column chromatography. Solution NMR spectra $\left({ }^{1} \mathrm{H}\right.$ and $\left.{ }^{13} \mathrm{C}\right)$ were recorded on a Bruker AVANCE 300, 400 or 600 MHZ spectrometer. ${ }^{1} \mathrm{H}$ frequency of 300,400 or $600 \mathrm{MHz}$, respectively; ${ }^{13} \mathrm{C}$ frequency of 75 , 101 or $151 \mathrm{MHz}$. Chemical shifts $(\delta)$ are given in $\mathrm{ppm} \mathrm{CDCl}_{3}$ residual chloroform signal as reference. IR spectra were recorded with a Tensor 27 (ATR diamond) Bruker spectrometer. Only the most important bands were reported, in wavenumbers $\bar{v}\left(\mathrm{~cm}^{-1}\right)$. NMR and IR spectroscopy experiments were performed at $300 \mathrm{~K}$. HRMS spectra were recorded at the Institut Parisien de Chimie Moléculaire (FR 2769) of UPMC (electrospray source). Cytotoxicity measurements on MCF-7 and MDA-MB-231 breast cancer cells were performed ImaGIF Ciblothèque Cellulaire (Institut de Chimie des Substances Naturelles).

Synthesis and analytical data of some intermediates ( $\mathbf{3}^{\prime}$ and $\mathbf{3}^{\prime}$ ') and by-products $\left(\mathbf{C}^{\prime}\right.$ and $\left.\mathbf{7}\right)$ are described only in the SI.

O-Ferrocenylpodophyllotoxin 1. To a suspension of ferrocenylcarboxylic acid (60 mg, 0.26 mmol, 3 equiv) in $1 \mathrm{~mL}$ of dry $\mathrm{CH}_{2} \mathrm{Cl}_{2}$ was added at room temperature oxalyl chloride (225 $\mu \mathrm{L}, 2.65 \mathrm{mmol}, 27$ equiv). After $30 \mathrm{~min}$ at room temperature, the solution took a deep red color. The mixture was concentrated in vaccuo to remove excess oxalyl chloride. Podophyllotoxin ( $38 \mathrm{mg}, 90 \mu \mathrm{mol}, 1$ equiv) was solubilizedequiv in $1.5 \mathrm{~mL}$ of dry $\mathrm{CH}_{2} \mathrm{Cl}_{2}$ and $\mathrm{Et}_{3} \mathrm{~N}$ (15 $\mu \mathrm{L}, 0.11 \mathrm{mmol}, 1.2$ equiv) was added. To this mixture was added at $0{ }^{\circ} \mathrm{C}$ ferrocenoyl chloride in $2 \mathrm{~mL}$ of $\mathrm{CH}_{2} \mathrm{Cl}_{2}$. Then a few crystals of DMAP were added and the mixture was stirred at $0{ }^{\circ} \mathrm{C}$ for $30 \mathrm{~min}$ and at room temperature for $1 \mathrm{~h}$. Reaction was quenched by addition of water, extracted with $\mathrm{CH}_{2} \mathrm{Cl}_{2}$ (3x), washed with diluted $\mathrm{HCl}(\sim 0.1$ $\mathrm{N})$, dried over $\mathrm{MgSO}_{4}$ and concentrated under vacuum. The crude product was purified by preparative TLC on silica (AcOEt/Cyclohexane 2/3) to yield $35 \mathrm{mg}$ of the desired compound as an orange powder $(60 \%) .{ }^{1} \mathrm{H}$ NMR $\left(400 \mathrm{MHz}, \mathrm{CDCl}_{3}\right): \delta(\mathrm{ppm}) 6.90(\mathrm{~s}, 1 \mathrm{H}), 6.58(\mathrm{~s}, 1 \mathrm{H})$, 
$6.44(\mathrm{~s}, 2 \mathrm{H}), 6.04-5.97(\mathrm{~m}, 3 \mathrm{H}), 4.85(\mathrm{dt}, J=2.5,1.3 \mathrm{~Hz}, 1 \mathrm{H}), 4.81(\mathrm{dt}, J=2.5,1.3 \mathrm{~Hz}, 1 \mathrm{H})$, $4.64(\mathrm{~d}, J=4.3 \mathrm{~Hz}, 1 \mathrm{H}) 4.50-4.44(\mathrm{~m}, 3 \mathrm{H}), 4.30(\mathrm{~m}, 1 \mathrm{H}), 4.25(\mathrm{~s}, 5 \mathrm{H}), 3.81(\mathrm{~s}, 3 \mathrm{H}), 3.80(\mathrm{~s}$, $6 \mathrm{H}), 3.02-2.87(\mathrm{~m}, 2 \mathrm{H}) .{ }^{13} \mathrm{C} \mathrm{NMR}\left(101 \mathrm{MHz}, \mathrm{CDCl}_{3}\right): \delta$ (ppm) 173.8, 172.6, 152.8, 148.3, $147,8,137.4,135.1,132.5,129.0,109.9,108.4$, 107.1, 101.8, 73.5, 72.1, 72.0, 71.8, 70.4, 70.3, 70.0, 61.0, 56.3, 45.8, 43.9, 39.1. IR (neat, $\mathrm{cm}^{-1}$ ): 1780, 1711, 1485, 1240, 1128. Exact mass $\left(\mathrm{C}_{33} \mathrm{H}_{30} \mathrm{FeO}_{9}\right)$ : calculated $649.1132(\mathrm{M}+\mathrm{Na})^{+}$, measured 649.1121.

(6-Bromobenzo[1,3]dioxol-5-yl)(pherrocenyl)methanol C. First synthesis: To a suspension of $\mathrm{LiAlH}_{4}\left(138.2 \mathrm{mg}, 3.64 \mathrm{mmol}, 3\right.$ equiv) in $2 \mathrm{~mL}$ THF at $-78{ }^{\circ} \mathrm{C}$ was added dropwise a solution of 3"' (505.3 mg, $1.23 \mathrm{mmol}, 1$ equiv) in $3 \mathrm{~mL}$ THF. The mixture was stirred $45 \mathrm{~min}$ at $-78{ }^{\circ} \mathrm{C}$, quenched by a saturated aqueous solution of $\mathrm{NH}_{4} \mathrm{Cl}$ and extracted with $\mathrm{Et}_{2} \mathrm{O}$. The organic layer was washed with brine, dried over $\mathrm{MgSO}_{4}$ and concentrated under vacuum. The crude product was purified by flash chromatography on silica (AcOEt/Cyclohexane 1:9) to yield $236.4 \mathrm{mg}(47 \%)$ of $\mathbf{C}$ and $62 \mathrm{mg}(10 \%)$ of $\mathbf{C}$ '.

Second synthesis: To a solution of ferrocene $(1.86 \mathrm{~g}, 10 \mathrm{mmol}, 1.2$ equiv) in $10 \mathrm{~mL}$ of a $1: 1$ mixture of THF and hexane, was added dropwise at $0{ }^{\circ} \mathrm{C}$ a solution of $t \mathrm{BuLi}(1.7 \mathrm{M}$ in hexanes, $5.9 \mathrm{~mL}, 1.2$ equiv). After $30 \mathrm{~min}$ at $0{ }^{\circ} \mathrm{C}$, the ice bath was removed and the mixture was placed in an acetone/ $\mathrm{N}_{2}$ liquid bath. Then, 6-bromopiperonal 3 (1.83 g, 8 mmol, 1 equiv) in $20 \mathrm{~mL}$ of THF was added dropwise to the dark red solution. After $1 \mathrm{~h}$ the reaction mixture was quenched by a saturated aqueous solution of $\mathrm{NH}_{4} \mathrm{Cl}$ and extracted with $\mathrm{Et}_{2} \mathrm{O}$. The organic layer was washed with brine, dried over $\mathrm{MgSO}_{4}$ and concentrated under vacuum. The crude product was purified by flash chromatography on silica (AcOEt/Cyclohexane from 5/95 to 10/90) to yield $1.47 \mathrm{~g}(44 \%)$ of C. ${ }^{1} \mathrm{H}$ NMR (400 MHz, $\left.\mathrm{CDCl}_{3}\right) \delta(\mathrm{ppm}) 7.08$ (s, 1H), 6.94 (s, $1 \mathrm{H}), 5.94(\mathrm{~d}, J=1.4 \mathrm{~Hz}, 1 \mathrm{H}), 5.92(\mathrm{~d}, J=1.4 \mathrm{~Hz}, 1 \mathrm{H}), 5.76(\mathrm{~d}, J=3.0 \mathrm{~Hz}, 1 \mathrm{H}), 4.38-4.15(\mathrm{~m}$, $4 \mathrm{H}), 4.26(\mathrm{~s}, 5 \mathrm{H}), 2.65(\mathrm{~d}, J=3.1 \mathrm{~Hz}, 1 \mathrm{H}) .{ }^{13} \mathrm{C} \mathrm{NMR}\left(101 \mathrm{MHz}, \mathrm{CDCl}_{3}\right) \delta$ (ppm) 147.8, 147.7, 136.1, 112.8, 112.5, 107.8, 101.8, 93.9, 70.5, 68,7, 68.4, 68.0, 67.7, 65.9. IR (neat, $\mathrm{cm}^{-}$ $\left.{ }^{1}\right)$ : 3559, 2914, 1498, 1470. Exact mass $\left(\mathrm{C}_{18} \mathrm{H}_{15} \mathrm{O}_{3} \mathrm{FeBr}\right)$ : calculated $436.94462(\mathrm{M}+\mathrm{Na})^{+}$, measured 436.94438.

Ethyl 2-((6-bromobenzo[1,3]dioxol-5-yl)(pherrocenyl)methyl)-3-oxobutanoate 4. To a solution of $\mathbf{C}$ (1.3 g, $3 \mathrm{mmol}, 1$ equiv) in $4 \mathrm{~mL}$ of $\mathrm{CH}_{2} \mathrm{Cl}_{2}$ were added ethyl acetoacetate (0.38 $\mathrm{mL}, 3 \mathrm{mmol}, 1$ equiv) and $\mathrm{TsOH}(26 \mathrm{mg}, 0.15 \mathrm{mmol}, 5 \mathrm{~mol} \%)$. The mixture was stirred at reflux during 1 hour until completion monitored by TLC, quenched by a saturated aqueous solution of $\mathrm{NaHCO}_{3}$ and extracted with $\mathrm{CH}_{2} \mathrm{Cl}_{2}$. The organic layer was washed with brine, 
dried over $\mathrm{MgSO}_{4}$ and concentrated under vacuum. The crude product was purified by flash chromatography on silica (AcOEt/Cyclohexane 2:8) to yield $934 \mathrm{mg}(75 \%)$ of $\mathbf{4}$ as a 50/50 diastereomeric mixture. ${ }^{1} \mathrm{H} \mathrm{RMN}\left(300 \mathrm{MHz}, \mathrm{CDCl}_{3}\right.$, diastereomeric mixture) $\delta(\mathrm{ppm}) 7.09(\mathrm{~s}$, $1 \mathrm{H}$, diast. 1), 7.08 (s, $1 \mathrm{H}$, diast. 2), 6.86 (s, 1H, diast. 1), 6.79 (s, 1H, diast. 2), 6.01 (d, $J=1.4$ $\mathrm{Hz}, 2 \mathrm{H}$, diast. 1), 5.99 (d, $J=1.3 \mathrm{~Hz}, 2 \mathrm{H}$, diast. 2), 4.98-4.94 (m, 2H, diast. 1 and 2), 4.11$3.92(\mathrm{~m}, 24 \mathrm{H}$, diast. 1 and 2), 2.08 (s, 6H, diast. 1 and 2), $1.16(\mathrm{t}, J=7.2 \mathrm{~Hz}, 3 \mathrm{H}$, diast. 1), 1.03 (t, $J=7.3 \mathrm{~Hz}, 3 \mathrm{H}$, diast. 2). ${ }^{13} \mathrm{C} \mathrm{NMR}\left(101 \mathrm{MHz}, \mathrm{CDCl}_{3}\right.$, diastereomeric mixture ) $\delta$ (ppm) 201.2 (diast. 1), 201.1 (diast. 2), 167.8 (diast. 1), 166.7 (diast. 2), 147.5 (diast. 1), 147.2 (diast. 2 et diast. 1), 146.9 (diast. 2), 134.7 (diast. 2), 133.9 (diast. 1), 115.8 (diast. 2), 115.4 (diast. 1), 112.7 (diast. 1), 112.6 (diast. 2), 108.3 (diast. 1), 108.1 (diast. 2), 101.9 (diast. 1), 101.8 (diast. 2), 89.6 (diast. 1), 89.5 (diast. 2), 69.9, 69.4, 68.8, 68.2, 68.1, 67.5, 66.9, 66.7 (diast. 1 et diast. 2), 65.6 (diast. 1), 65.3 (diast. 2), 61.5 (diast. 2), 61.3 (diast. 1), 43.1 (diast. 1), 42.8 (diast. 2), 30.9 (diast. 1), 28.1 (diast. 2), 14.0 (diast. 1), 13.8 (diast. 2). IR (neat, $\mathrm{cm}^{-1}$ ): 2901, 2981, 1731, 1503, 1477, 1221, 1153, 1035. Exact mass $\left(\mathrm{C}_{24} \mathrm{H}_{23} \mathrm{BrFeO}_{5} \mathrm{Na}\right)$ : calculated $548.9972(\mathrm{M}+\mathrm{Na})^{+}, 548.9967$ measured.

\section{Ethyl 2-acetyl-2-((6-bromobenzo[1,3]dioxol-5-yl)(pherrocenyl)methyl)pent-4-enoate 5.}

Starting from the alcohol $\mathbf{C}$, third essay (via chloride intermediate): To a solution of $\mathbf{C}$ (100 $\mathrm{mg}, 0.24 \mathrm{mmol}, 1$ equiv) in $1 \mathrm{~mL}$ of THF, was added 2,6-lutidine (42 $\mu \mathrm{L}, 0.36 \mathrm{mmol}, 1.5$ equiv.) followed by a dropwise addition of oxalyl chloride ( $25 \mu \mathrm{L}, 0.29 \mathrm{mmol}, 1.2$ equiv). The mixture was stirred at room temperature during $90 \mathrm{~min}$. Separately, ethyl 2-acetylpent-4enoate ( $80 \mathrm{mg}, 0.5 \mathrm{mmol}, 2$ equiv) was added on a suspension of sodium hydride $(23 \mathrm{mg}$, $0.57 \mathrm{mmol}, 2.4$ equiv) in $1 \mathrm{~mL}$ of THF. This solution was cannulated on the solution of $\mathbf{C}$. After overnight at room temperature, the reaction was quenched by a saturated aqueous solution of $\mathrm{NH}_{4} \mathrm{Cl}$ and extracted with $\mathrm{Et}_{2} \mathrm{O}$. The organic layer was washed with a solution of $\mathrm{HCl} 0.1 \mathrm{~N}$, then with brine, dried over $\mathrm{MgSO}_{4}$ and concentrated under vacuum. The crude product was purified by flash chromatography on silica $\left(\mathrm{CH}_{2} \mathrm{Cl}_{2} / \mathrm{Cyclohexane} 1: 1\right)$ to yield 90 $\mathrm{mg}(65 \%)$ of 5 as a 50/50 diastereomeric mixture. ${ }^{1} \mathrm{H} \mathrm{RMN}\left(400 \mathrm{MHz}, \mathrm{CDCl}_{3}\right.$, diastereomeric mixture) $\delta(\mathrm{ppm}) 7.13(\mathrm{~s}, 1 \mathrm{H}$, diast. 1), 7.11 (s, 1H, diast. 2), $7.06(\mathrm{~s}, 1 \mathrm{H}$, diast. 1), 6.85 (s, $1 \mathrm{H}$, diast. 2), 6.05-6.04 (m, 2H, diast. 1), 6.02-6.01 (m, 2H, diast. 2), 5.65-5.39 (m, 2H, diast. 1 and 2), 5.37 (s, $1 \mathrm{H}$, diast. 1), 5.35 (s, $1 \mathrm{H}$, diast. 2), 4.97-4.86 (m, 4H, diast. 1 and 2), 4.39$3.83(\mathrm{~m}, 12 \mathrm{H}$, diast. 1 and 2), 3.94 (s, 5H, diast. 1), 3.92 (s, 5H, diast. 2), 2.57-2.44 (m, 2H, diast. 1), 2.42-2.31 (m, 2H, diast. 2), 2.03 (s, 3H, diast. 1), 1.76 (s, 3H, diast. 2), 1.26 (t, $J=$ $7.2 \mathrm{~Hz}, 3 \mathrm{H}$, diast. 1), 1.10 (t, $J=7.2 \mathrm{~Hz}, 3 \mathrm{H}$, diast. 2$).{ }^{13} \mathrm{C} \mathrm{NMR}\left(101 \mathrm{MHz}, \mathrm{CDCl}_{3}\right.$, 
diastereomeric mixture) $\delta$ (ppm) 206.6 (diast. 1), 204.6 (diast. 2), 171.9 (diast. 1), 171.7 (diast. 2), 147.4, 147.3, 147.2, 147.1 (diast. 1 and 2), 133.8 (diast. 1), 133.1 (diast. 2), 132.8 (diast. 1), 132.2 (diast. 2), 118.8 (diast. 1), 118.0 (diast. 2), 117.5 (diast. 1 and 2), 112.8 (diast. 1 and 2), 110.1 (diast. 1), 101.0 (diast. 2), 102.1 (diast. 1), 102.0 (diast. 2), 88.1 (diast. 1), 87.9 (diast. 2), 71.4, 69.6, 69.0, 68.8, 68.4, 68.1, 67.7, 67.3 (diast. 1 and 2), 69.6 (diast. 1), 69.5 (diast. 2), 69.0 (diast. 1), 68.8 (diast. 2), 61.4 (diast. 1), 61.3 (diast. 2), 47.9 (diast. 1), 47.2 (diast. 2), 39.5 (diast. 1), 39.3 (diast. 2), 31.7 (diast. 1), 30.3 (diast. 2), 14.2 (diast. 1), 13.8 (diast. 2). IR (neat, $\mathrm{cm}^{-1}$ ): 3079, 1730, 1700, 1638, 1503, 1478. Exact mass $\left(\mathrm{C}_{27} \mathrm{H}_{27} \mathrm{BrFeO}_{5}\right)$ : calculated 589.0285 $(\mathrm{M}+\mathrm{Na})^{+}$, measured 589.0301.

\section{Ethyl 6-acetyl-8-methylene-5-pherrocenyl-5,6,7,8-tetrahydronaphtho[2,3- $d][1,3]$ dioxole-}

6-carboxylate 8. To a solution of $\mathrm{Pd}(\mathrm{OAc})_{2}(28.0 \mathrm{mg}, 0.12 \mathrm{mmol}, 10 \mathrm{~mol}-\%)$, dppe (100.3 $\mathrm{mg}, 0.25 \mathrm{mmol}, 20 \mathrm{~mol}-\%)$ and $\mathrm{K}_{2} \mathrm{CO}_{3}(345.3 \mathrm{mg}, 0.24 \mathrm{mmol}, 2$ equiv) in $2.3 \mathrm{~mL}$ of DMF was added 3 (706.2 mg, $1.25 \mathrm{mmol}, 1$ equiv) in $16.3 \mathrm{~mL}$ of DMF and the mixture was heated at $130{ }^{\circ} \mathrm{C}$ for $18 \mathrm{~h}$. The reaction was quenched by a saturated aqueous solution of $\mathrm{NH}_{4} \mathrm{Cl}$ and extracted with $\mathrm{Et}_{2} \mathrm{O}$. The organic layer was washed intensively with diluted $\mathrm{HCl}(0.1 \mathrm{~N})$, then with brine, dried over $\mathrm{MgSO}_{4}$ and concentrated under vacuum. The crude product was purified by flash chromatography on silica (AcOEt/Cyclohexane 15/85) to yield $508.7 \mathrm{mg}$ $(84 \%)$ of 8 as a $60 / 40$ diastereomeric mixture. ${ }^{1} \mathrm{H}$ NMR $\left(300 \mathrm{MHz}, \mathrm{CDCl}_{3}\right.$, diastereomeric mixture) $\delta(\mathrm{ppm}) 7.11$ (s, 1H, minor diast.), 7.08 (s, 1H, major diast.), 7.03 (s, 1H, major diast.), 7.01 (s, 1H, minor diast.), 6.00 (t, $J=1.2 \mathrm{~Hz}, 2 \mathrm{H}$, major and minor diast.), 5.96 (t, $J=$ $1.2 \mathrm{~Hz}, 2 \mathrm{H}$, major and minor diast.), 5.45 (s, 2H, major and minor diast.), 4.66-4.64 (m, 1H, minor diast.), 4.64-4.61 (m, 1H, major diast.), 4.27-3.93 (m, 12H, major and minor diast.), 4.10 (s, 5H, major diast.), 4.08 (s, 5H, minor diast.), 3.46-3.43 (m, 1H, minor diast.), 3.423.40 (m, 1H, major diast.), 3.06-3.01 (m, 1H, minor diast.), 3.00-2.95 (m, 1H, major diast.), 2.89-2.87 (m, 1H, major diast.), 2.83-2.81 (m, 1H, minor diast.), 2.15 (s, 3H, minor diast.), 2.10 (s, 3H, major diast.), 1.27 (t, $J=7.1 \mathrm{~Hz}, 6 \mathrm{H}$, major diast.), 1.04 (t, $J=7.1 \mathrm{~Hz}, 6 \mathrm{H}$, minor diast.). ${ }^{13} \mathrm{C} \mathrm{NMR}\left(75 \mathrm{MHz}, \mathrm{CDCl}_{3}\right.$, diastereomeric mixture) $\delta$ (ppm) 204.7 (minor diast.), 202.9 (major diast.), 170.0 (minor diast.), 169.8 (major diast.), 147.6, 147.5, 147.3, 147.2 (major and minor diast.), 138.8 (minor diast.), 138.5 (major diast.), 132.1 (minor diast.), 131.6 (major diast.), 127.5 (major diast.), 127.4 (minor diast.) 110.5 (major diast.), 110.4 (minor diast.), 109.4 (major diast.), 109.2 (minor diast.), 103.4 (major diast.), 103.3 (minor diast.), 101.3 (major diast.), 101.2 (minor diast.), 90.2, 89.3, 69.4, 69.3, 69.0, 67.7, 67.0 (major and minor diast.), 66.3 (major diast.), 65.6 (minor diast.), 61.7 (major diast.), 61.6 (minor diast.), 
45.6 (minor diast.), 45.1 (major diast.), 32.0 (minor diast.), 31.7 (major diast.), 26.3 (minor diast.), 26.2 (major diast.), 14.1 (major diast.), 13.9 (minor diast.). IR (neat, $\mathrm{cm}^{-1}$ ): 3087, 1737, 1713, 1503, 1480. Exact mass $\left(\mathrm{C}_{27} \mathrm{H}_{26} \mathrm{FeO}_{5}\right)$ : calculated 509.1022 $(\mathrm{M}+\mathrm{Na})^{+}$, measured 509.1018 .

\section{Ethyl 8-methylene-5-pherrocenyl-5,6,7,8-tetrahydronaphtho[2,3- $d][1,3]$ dioxole-6-}

carboxylate 9. To a solution of sodium ethylate formed by reacting $\mathrm{Na}$ (30 $\mathrm{mg}, 1.3 \mathrm{mmol}, 1.5$ equiv) in $5 \mathrm{~mL}$ of absolute EtOH was added 8 (430 mg, $0.885 \mathrm{mmol}, 1$ equiv) in $5 \mathrm{~mL}$ THF. The mixture was brought to reflux for $3 \mathrm{~h}$, then the reaction was quenched by addition of $\mathrm{HCl}$ $0.2 \mathrm{~N}$ and extracted with $\mathrm{Et}_{2} \mathrm{O}$. The organic layer was washed with brine, dried over $\mathrm{MgSO}_{4}$ and concentrated under vacuum. The crude product was purified by flash chromatography on silica (AcOEt/Cyclohexane 5/95 -> 10/90) to yield $370 \mathrm{mg}(95 \%)$ of ester 9 as a 65/35 diastereomeric mixture. ${ }^{1} \mathrm{H} \mathrm{NMR}\left(400 \mathrm{MHz}, \mathrm{CDCl}_{3}\right.$, diastereomeric mixture) $\delta(\mathrm{ppm}) 7.17(\mathrm{~s}$, 1H, minor diast.), 7.08 (s, 1H, major diast.), 6.93 (s, 1H, minor diast.), 6.92 (s, 1H, major diast.), 6.01 (d, $J=1.1 \mathrm{~Hz}, 1 \mathrm{H}$, minor diast.), 6.00-5.98 (m, 1H, minor diast.), 5.96 (d, $J=1.2$ $\mathrm{Hz}, 1 \mathrm{H}$, major diast.), 5.94 (d, $J=1.1 \mathrm{~Hz}, 1 \mathrm{H}$, major diast.), 5.44-5.42 (m, 1H, minor diast.), 5.40-5.33 (m, 1H, major diast.), 4.91-4.89 (m, 1H, minor diast.), 4.89-4.85 (m, 1H, major diast.), 4.36-4.32 (m, 1H, major diast.), 4.30-4.29 (m, 1H, minor diast.), 4.23-3.99 (m, 10H, major and minor diast.), 4.17 (s, 5H, major diast.), 4.12 (s, 5H, minor diast.), 3.67-3.64 (m, $1 \mathrm{H}$, major diast.), 3.47-3.45 (m, 1H, minor diast.), 3.03-2.85 (m, 2H, major and minor diast.), 2.81-2.52 (m, 4H, major and minor diast.), 1.31 (t, $J=7.1 \mathrm{~Hz}, 3 \mathrm{H}$, minor diast.), 1.16 (t, $J=$ $7.1 \mathrm{~Hz}, 3 \mathrm{H}$, major diast.). ${ }^{13} \mathrm{C} \mathrm{NMR}\left(101 \mathrm{MHz}, \mathrm{CDCl}_{3}\right.$, diastereomeric mixture) $\delta(\mathrm{ppm})$ 173.9 (major diast.), 173.3 (minor diast.), 147.4, 147.2, 147.1, 146.9 (major and minor diast.), 140.6 (minor diast.), 139.6 (major diast.), 133.2 (minor diast.), 131.2 (major diast.), 128.4 (minor diast.), 128.1 (major diast.), 109.8 (major and minor diast.), 108.4 (major and minor diast.), 103.9 (major and minor diast.), 101.2 (minor diast.), 101.1 (major diast.), 93.8, 89.7, 69.6, 69.3, 69.0, 68.8, 68.0, 67.9, 67.2, 66.9, 66.8, 66.3 (major and minor diast.), 60.7 (major diast.), 60.6 (minor diast.), 47.2 (major diast., 45.7 (minor diast.), 42.9) (minor diast., 41.2 (major diast.), 30.2 (major diast.), 28.4 (minor diast.), 14.4 (minor diast.), 14.3 (major diast.). IR (neat, $\left.\mathrm{cm}^{-1}\right)$ : 3085, 1729, 1503, 1480. Exact mass $\left(\mathrm{C}_{25} \mathrm{H}_{24} \mathrm{FeO}_{4}\right)$ : calculated 467.0916 $(\mathrm{M}+\mathrm{Na})^{+}$, measured 467.0931.

Ethyl 8-oxo-5-pherrocenyl-5,6,7,8-tetrahydronaphtho[2,3- $d][1,3]$ dioxole-6-carboxylate A. To a solution of ester 9 (550 mg, 1.24 mmol, 1 equiv) in a 9:1 mixture of $\mathrm{THF} / \mathrm{H}_{2} \mathrm{O}(30$ 
$\mathrm{mL}$ ) was added $N$-methylmorpholine oxide monohydrate (370 mg, 2.74, 2.2 equiv) and $\mathrm{OsCl}_{3}$ (40 mg, $0.12 \mathrm{mmol}, 10 \mathrm{~mol}-\%$ ). The mixture was stirred at room temperature for $20 \mathrm{~h}$, quenched with a $50 \%$ aqueous solution of $\mathrm{NaHSO}_{3}$, and extracted with AcOEt. The organic phase was washed with brine, dried over $\mathrm{MgSO}_{4}$ and concentrated under vacuum. The crude product was solubilised in $30 \mathrm{~mL}$ of a 2:1 mixture of acetone and water and $\mathrm{NaIO}_{4}(630 \mathrm{mg}$, $2.95 \mathrm{mmol}, 2.4$ equiv) was added. After $3 \mathrm{~h}$ at room temperature, the reaction mixture was quenched with a saturated aqueous solution of $\mathrm{Na}_{2} \mathrm{~S}_{2} \mathrm{O}_{3}$, and extracted with $\mathrm{Et}_{2} \mathrm{O}$. The organic phase was washed with brine, dried over $\mathrm{MgSO}_{4}$ and concentrated under vacuum. The crude product was purified by flash chromatography on silica (AcOEt/Cyclohexane 5/95) to yield $330 \mathrm{mg}(60 \%)$ of $\mathbf{A}$ as a 65/35 diastereomeric mixture. ${ }^{1} \mathrm{H}$ NMR $\left(300 \mathrm{MHz}, \mathrm{CDCl}_{3}\right.$, diastereomeric mixture) $\delta 7.49$ (s, 1H, minor diast.), 7.47 (s, 1H, major diast.), $7.04(\mathrm{~s}, 1 \mathrm{H}$, minor diast.), 6.95 (s, 1H, major diast.), 6.10 (d, $J=1.2 \mathrm{~Hz}, 1 \mathrm{H}$, minor diast.), 6.08-6.07 (m, $2 \mathrm{H}$, major and minor diast.), 6.04 (d, $J=1.3 \mathrm{~Hz}, 1 \mathrm{H}$, major diast.), 4.50-4.47 (m, 2H, major and minor diast.), 4.28-4.00 (m, 21H, major and minor diast.), 3.47-3.43 (m, 1H, major diast.), 3.34-3.26 (m, 1H, minor diast.), 3.14 (dt, $J=5.1,2.5 \mathrm{~Hz}, 1 \mathrm{H}$, major diast.), 2.84-2.80 (m, 1H, minor diast.), 2.76-2.75 (m, 1H, major diast.), 2.64-2.43 (m, 2H, major and minor diast.), 1.29 (t, $J=7.2 \mathrm{~Hz}, 3 \mathrm{H}$, minor diast.) 1.11 (t, $J=7.1 \mathrm{~Hz}, 3 \mathrm{H}$, major diast.). ${ }^{13} \mathrm{C}$ NMR (101 MHz, $\mathrm{CDCl}_{3}$, diastereomeric mixture) $\delta$ (ppm) 195.5 (minor diast.), 194.0 (major diast.), 172.8 (major diast.), 171.9 (minor diast.), 152.2 (major and minor diast.), 147.8 (major and minor diast.), 141.5 (minor diast.), 139.2 (major diast.), 127.6 (minor diast.), 127.3 (major diast.), 109.3 (major diast.), 109.2 (minor diast.), 106.5 (minor diast.), 106.4 (major diast.), 102.1 (minor diast.), 101.9 (major diast.), 91.6 (major diast.), 88.0 (minor diast.), 69.1, 69.0, 68.88, 68.6, 68.5, 67.7, 67.4, 67.3, 67.2, 66.6 (major and minor diast.), 61.2 (major diast.), 61.1 (minor diast.), 48.1 (major diast.), 46.1 (minor diast.), 42.1 (minor diast.), 42.0 (major diast.), 35.4 (minor diast.), 35.2 (major diast.), 14.4 (minor diast.), 14.2 (major diast.). IR (neat, $\mathrm{cm}^{-1}$ ): 1725, 1671, 1478, 1256. Exact mass $\left(\mathrm{C}_{24} \mathrm{H}_{22} \mathrm{FeO}_{5}\right)$ : calculated $469.0709(\mathrm{M}+\mathrm{Na})^{+}$, measured 469.0704 .

\section{Ethyl 8-hydroxy-5-pherrocenyl-5,6,7,8-tetrahydronaphtho[2,3- $d][1,3]$ dioxole-6-}

carboxylate $2(\mathrm{R}=\mathrm{Et}) . \gamma$-Oxo-ester A ( $80 \mathrm{mg}, 0.18 \mathrm{mmol}, 1$ equiv) was dissolved in $\mathrm{EtOH}(5$ $\mathrm{mL})$ and THF (2 mL). The solution is canulated over $\mathrm{NaBH}_{4}(14 \mathrm{mg}, 0.57 \mathrm{mmol}, 3$ equiv) in $2 \mathrm{~mL}$ EtOH. The mixture was stirred at room temperature. The reaction progressed slowly. After $15 \mathrm{~h}$ (overnight) starting material has disappeared but ester was partially reducted. The reaction mixture was then purified by preparative TLC (AcOEt/cyclohexane 2:3) to yield 20 
$\mathrm{mg}(25 \%)$ of alcohol $2(\mathrm{R}=\mathrm{Et})$ as two isolated diastereoisomers $(75 / 25)$. Second product is the diol in mixture with degradation. ${ }^{1} \mathrm{H} \mathrm{NMR}\left(400 \mathrm{MHz}, \mathrm{CDCl}_{3}\right.$, major diast.): $\delta$ (ppm) 7.04 (s, 1H), 6.98 (s, 1H), 6.00 (d, $J=1.3 \mathrm{~Hz}, 1 \mathrm{H}), 5.97$ (d, $J=1.3 \mathrm{~Hz}, 1 \mathrm{H}), 4.74-4.64(\mathrm{~m}, 1 \mathrm{H})$, $4.25(\mathrm{~d}, J=3.8 \mathrm{~Hz}, 1 \mathrm{H}), 4.18-4.10(\mathrm{~m}, 8 \mathrm{H}), 4.05-4.02(\mathrm{~m}, 1 \mathrm{H}), 4.01-3.99(\mathrm{~m}, 1 \mathrm{H}), 3.45-3.43$ (m, 1H), 2.91 (ddd, $J=12.5,4.0,2.6 \mathrm{~Hz}, 1 \mathrm{H}), 2.33-2.22(\mathrm{~m}, 1 \mathrm{H}), 1.84(\mathrm{~d}, J=7.9 \mathrm{~Hz}, 1 \mathrm{H})$, 1.73 (ddd, $J=13.4,12.59 .4 \mathrm{~Hz}, 1 \mathrm{H} 1.29$ (t, $J=8.2 \mathrm{~Hz}, 3 \mathrm{H}) .{ }^{13} \mathrm{C} \mathrm{NMR}\left(101 \mathrm{MHz}, \mathrm{CDCl}_{3}\right.$, major diast.): $\delta$ (ppm) 173.3, 147.1, 146.7, 132.5, 131.4, 101.2, 91.1, 70.3, 69.1, 69.0, 68.1, 67.2, 66.7, 60.8, 45.4, 41.7, 30.2, 14.3. ${ }^{1} \mathrm{H} \mathrm{NMR}$ (400 $\mathrm{MHz}, \mathrm{CDCl}_{3}$, minor diast.): $\delta$ (ppm) $6.96(\mathrm{~s}, 1 \mathrm{H}), 6.88(\mathrm{~s}, 1 \mathrm{H}), 5.93(\mathrm{~d}, 1 \mathrm{H}, J=2.0 \mathrm{~Hz}), 4.79-4.70(\mathrm{~m}, 1 \mathrm{H}), 4.27$ (d, 1H, $J=4.0$ $\mathrm{Hz}), 4.23-4.06$ (m, 10H), 3.81 (s, 1H), 3.49 (s, 1H), 3.18-3.11 (m, 1H), 2.30-2.21 (m, 1H), $1.94(\mathrm{dd}, J=8.2,4.5 \mathrm{~Hz}, 1 \mathrm{H}), 1.62-1.50(\mathrm{~m}, 1 \mathrm{H}), 1.25(\mathrm{t}, J=7.1 \mathrm{~Hz}, 3 \mathrm{H}) .{ }^{13} \mathrm{C} \mathrm{NMR}(101$ $\mathrm{MHz}, \mathrm{CDCl}_{3}$, minor diast.): $\delta$ (ppm) 174.6, 147.2, 146.7, 131.4, 131.1, 109.7, 107.7, 101.1, $69.5,69.2,68.2,67.2,67.1,66.4,61.0,51.0,46.0,39.6,32.2,14.4$. IR (neat, $\mathrm{cm}^{-1}$ ): 3519, 1716, 1480, 1226. Exact mass $\left(\mathrm{C}_{24} \mathrm{H}_{24} \mathrm{FeO}_{5}\right)$ : calculated $448.0968(\mathrm{M}+\mathrm{Na})^{+}$, measured 448.0979 .

Cell culture and cell proliferation assay. The breast adenocarcinoma cell lines MDA-MB231 and MCF-7 were obtained respectively from ATCC and Dr Matthias Kassack (Bonn, Germany). Cells were grown in RPMI medium supplemented with $10 \%$ fetal calf serum, in the presence of penicilline, streptomycine and fungizone in $75 \mathrm{~cm}^{2}$ flask under $5 \% \mathrm{CO}$. Cells were plated in 96-well tissue culture plates in $200 \mu \mathrm{l}$ medium and treated $24 \mathrm{~h}$ later with $2 \mu \mathrm{l}$ stock solution of compounds dissolved in DMSO using a Biomek 3000 (Beckman-Coulter). Controls received the same volume of DMSO (1\% final volume). After $72 \mathrm{~h}$ exposure, MTS reagent (Promega) was added and incubated for $3 \mathrm{~h}$ at $37^{\circ} \mathrm{C}$ : the absorbance was monitored at $490 \mathrm{~nm}$ and results expressed as the inhibition of cell proliferation calculated as the ratio [(1$($ OD490 treated/OD490 control) $) \times 100$ ] in triplicate experiments. For IC50 determination [50\% inhibition of cell proliferation], cells were incubated for $72 \mathrm{~h}$ following the same protocol with compound concentrations ranged $5 \mathrm{nM}$ to $100 \mu \mathrm{M}$ in separate duplicate experiments.

\section{Acknowledgements}

We thank Yasmine Reviriot for his contribution in preliminary experiments and Omar Khaled for HRMS analyses. CNRS, UPMC, and Labex Michem are acknowledged for financial 
support. Support through CMST COST Action, CM1205 (CARISMA) is also gratefully acknowledged.

\section{Appendix. Supplementary material}

NMR spectra of all new compounds. Supplementary data associated with this article can be found, in the online version, at ...

\section{References}

[1] V. Podwyssotzki, Arch. Exp. Pathol. Pharmakol. 13 (1880) 29.

[2] M. Youesfadzi, M. Sharifi, M. Behmanesh, E. Moyano, M. Bonfill, R. M. Cuido, J. Palaon, Eng. Life Sci. 10 (2010) 281.

[3] a) R. M. Moraes, Stud. Nat. Prod. Chem. 26 (2002) 149. b) For review, see: H. Xu, M. Lv, X. Tian, Curr. Med. Chem. 16 (2009) 327, and references therein.

[4] For example, see: a) D. B. Berkowitz, S. Choi, J.-H. Maeng, J. Org. Chem. 65 (2000) 847. For recent reviews on synthesis of podophyllotoxin derivatives, see: b) M. Gordaliza, P. A. García, J. M. Miguel del Corral, M. A. Castro, M. A. Gómez-Zurita, Toxicon 44 (2004) 441. c) J. D. Sellars, P. G. Steel, Eur. J. Org. Chem. (2007) 3815.

[5] a) H. Stähelin, Eur. J. Cancer 9 (1973) 215. b) H. Stähelin, Eur. J. Cancer 6 (1970) 303.

[6] M. Gordaliza, M. A. Castro, J. M. Miguel del Corral, A. San Feliciano, Curr. Pharm. Des. 6 (2000) 1811.

[7] J. Hashemi, C. Worrall, D. Vasilcanu, M. Fryknäs, L. Sulaiman, M. Karimi, W. H. Weng, W.-O. Lui, C. Rudduck, M. Axelson, H. Jernberg-Wiklund, L. Girnita, O. Larsson, C. Larsson, PLoS One 6 (2011) e14757.

[8] For a recent example, see: A.Abad, J. L. Lopez-Perez, E. del Olmo, L. F. García-Fernandez, A. Francesch, C. Trigili, I. Barasoain, J. M. Andreu, J. F. Díaz, A. San Feliciano, J. Med. Chem. 55 (2012) 6724.

[9] A. Pelter, R. S. Ward, J. Nat. Prod. 57 (1994) 1598.

[10] a) G. Jaouen, Bioorganometallics, Wiley-VCH, Weinheim, (2006) and references therein. b) G. Jaouen, N. Metzler-Nolte, in Medicinal Organometallic Chemistry, Vol. 32, Spingerlink ed., (2010). c) G. Jaouen, M. Salmain, Bioorganometallic chemistry: Application in drug discovery, biocatalysis, and imaging, WileyVCH, Weinheim, (2015).

[11] For reviews, see: a) K. Strohfeldt, M. Tacke, Chem. Soc. Rev. 37 (2008) 1174. b) C. G. Hartinger, P. J. Dyson, Chem. Soc. Rev. 38 (2009) 391. c) G. Gasser, I. Ott, N. Metzler-Nolte, J. Med. Chem. 54 (2011) 3. d) G. Jaouen, S. Top, in Advances in Organometallic Chemistry and Catalysis, Ed.: A. J. L. Pombeiro, Wiley, Hoboken, New Jersey, USA, (2014) pp. 563.

[12] a) A. Vessières, S. Top, P. Pigeon, E. A. Hillard, L. Boubeker, D. Spera, G. Jaouen, J. Med. Chem. 48 (2005) 3937. b) E. A. Hillard, A. Vessières, F. Le Bideau, D. Plazuk, D. Spera, M. Huché, G. Jaouen, ChemMedChem 1 (2006) 551. c) D. Plazuk, A. Vessières, E. A. Hillard, O. Buriez, E. Labbé, P. Pigeon, M-A. Plamont, C. Amatore, J. Zakrzewski, G. Jaouen, J. Med. Chem. 52 (2009) 4964. 
[13] a) A. Nguyen, A. Vessieres, E. A. Hillard, S. Top, P. Pigeon, G. Jaouen, Chimia 67 (2007) 716. b) E. A. Hillard, G. Jaouen, Organometallics (2011) 20. c) G. Jaouen, A. Vessières, S. Top, Chem . Soc. Rev. 44 (2015) 8802 .

[14] a) S. S. Braga, A. M. S. Silva, Organometallics 32 (2013) 5626. b) F. Dubar, C. Slomianny, J. Khalife, D. Dive, H. Kalamou, Y. Guérardel, P. Grellier, C. Biot, Angew. Chem. Int. Ed. 52 (2013) 7690.

[15] D. Dive, C. Biot, ChemMedChem. 3 (2008) 383.

[16] Ferrocenoyl chloride was prepared according to: N. Malek-Saied, R. El Aissi, S. Ladeira, E. Benoist, Appl. Organometal. Chem. 25 (2011) 680.

[17] a) G. Poli, G. Giambastiani, J. Org. Chem. 67 (2002) 9456. b) F. Mingoia, M. Vitale, D. Madec, G. Prestat, G. Poli, Tetrahedron Lett. 49 (2008) 760. c) M. Vitale, G. Prestat, D. Lopes, D. Madec, C. Kammerer, G. Poli, L. Girnita, J. Org. Chem. 73 (2008) 5795.

[18] a) A. S. Kende, L. S. Liebeskind, J. E. Mills, P. S. Rutledge, D. P. Curran, J. Am. Chem. Soc. 99 (1977) 7082. b) A. S. Kende, M. L. King, D. P. Curran, J. Org. Chem. 46 (1981) 2826. c) T. Kaneko, H. Wong, Tetrahedron Lett. 28 (1987) 517.

[19] For nucleophilic substitution of ferrocenyl alcohol, see: a) G. W. Gokel, P. Hoffmann, H. Klusacek, D. Marquarding, E. Ruch, I. Ugi, Angew. Chem., Int. Ed. Engl. 9 (1970) 64. b) D. Marquarding, H. Klusacek, G. W. Gokel, P. Hoffmann I. Ugi, J. Am. Chem. Soc. 92 (1970) 5389. c) G. W. Gokel, D. Marquarding, I. Ugi, J. Org. Chem. 37 (1972) 3052. For recent examples, see: d) P. Vicennati, P. G. Cozzi, Eur. J. Org. Chem. (2007) 2248. e) P. G. Cozzi, L. Zoli, Green. Chem. 9 (2007) 1292.

[20] a) P. G. Cozzi, F. Benfatti, Angew. Chem. Int. Ed. 49 (2010) 256. b) A. Gualandi, D. Petruzziello, E. Emer, P. G. Cozzi, (2013) Alpha-Alkylation by SN1-Type Reactions, in Comprehensive Enantioselective Organocatalysis: Catalysts, Reactions, and Applications (ed P. I. Dalko), Wiley-VCH Verlag GmbH \& Co. KGaA, Weinheim, Germany.

[21] F. Bisaro, G. Prestat, M. Vitale, G. Poli, Synlett 11 (2002) 1823.

[22] A. Padwa, M. Dimitroff, A. G. Waterson, T. Wu, J. Org. Chem. 63 (1998) 3986.

[23] The reduction did not proceed with $\mathrm{NaBH}_{4}$, and must be conducted with $\mathrm{LiAlH}_{4}$ at low temperature to minimize dehalogenation of the aromatic ring.

[24] D. Guillaneux, H. B. Kagan, J. Org. Chem. 60 (1995) 2502.

[25] In this study, all chiral compounds were prepared as racemic mixtures.

[26] Other Brønsted acids $\left(\mathrm{H}_{2} \mathrm{SO}_{4}, \mathrm{TfOH}\right)$ in catalytic conditions, or Lewis acids $\left(\mathrm{BF}_{3} \cdot \mathrm{Et}_{2} \mathrm{O}, \mathrm{InBr}_{3}, \mathrm{TiCl}_{4}\right)$ in stoichiometric conditions were also tested and gave either lower yields or no reaction at all.

[27] T. M. Baker, L. A. Sloan, L. H. Choudhury, C. Murai, D. J. Procter, Tetrahedron: Asymmetry 21 (2010) 1247.

[28] R. Sanz, D. Miguel, A. Martínez, J. Álvarez-Gutiérrez, F. Rodríguez, Org. Lett. 9 (2007) 2027

[29] M. Wada, O. Mitunobu, Tetrahedron Lett. 13 (1972) 1279.

[30] a) T. Tsunoda, Y. Yamamiya, S. Itô, Tetrahedron Lett. 34 (1993) 1639. b) S. Chaturvedi, K. Otteson, J. Bergot, Tetrahedron Lett. 40 (1999) 8205. c) M. C. Hillier, J.-N.Derosiers, J.-F. Marcou, E. J. J. Grabowski, Org. Lett. 6 (2004) 573.

[31] S. Biswas, S. Maiti, U. Jana, Eur. J. Org. Chem. 15 (2010) 2861. 
[32] The relative stereochemistry of the major diastereoisomer of $\mathbf{B}$ could be deduced by the coupling constant (5.1 Hz) between the proton in $\mathrm{C} 2$ (carbon bearing the ferrocene) and the proton in $\mathrm{C} 3$ (carbon bearing the ester).

[33] Picropodophyllone could be converted into podophyllotoxin by $\mathrm{Zn}\left(\mathrm{BH}_{4}\right)_{2}$ reduction to give the cis-fused isomer picropodophyllin, followed by cis-trans isomerization according to the Gensler protocol. W. J. Gensler, C. Gatsonis, J. Org. Chem. 31, (1966) 4004.

[34] The relative C-2/C-3 stereochemistry of the major diastereoisomer in $\mathbf{1 3}$ (podophyllotoxin numbering) could be confidently deduced from the value of the vicinal coupling constant $\left({ }^{3} \mathrm{~J}_{2-3} \sim 4 \mathrm{~Hz}\right)$ in the ${ }^{1} \mathrm{H}$ NMR spectrum. On the other hand, we were unable to identify the relative stereochemistry with respect to C-4.

[35] The intermediates of the synthesis were not evaluated in the biological essay.

[36] S. Knauer, B. Biersack, M. Zoldakova, K. Effenberger, W. Milius, R. Schobert, Anticancer drugs, 20 (2009) 676

[37] E. Hillard, A.Vessières, F. Le Bideau, D. Plazuk, D. Spera , M. Huche, G. Jaouen, ChemMedChem 1 (2006) 551.

[38] a) A. Mooney,R. Tiedt, T. Maghoub,N. O’Donovan, J. Crown, B. White, PTM. Kenny, J. Med. Chem. 55 (2012) 5455. b) A. Wieczorek, B. Andrzej, J. Zacrzewski, B. Richlik, D. Plazuk, ACS Med Chem Lett. 7 (2016) 612 . 


\section{Highlights}

- Podophyllotoxin analogs have been synthesized

- The ferrocenyl moiety was grafted on podophyllotoxin and on an analog of it

- The importance of ferrocenyl conjugated motifs to generate antiproliferative effects is discussed. 


\section{Approach to Ferrocenyl-Podophyllotoxin Analogs and their Evaluation as Anti-Tumor Agents}

Matthieu Beaupérin, Dilan Polat, Fares Roudesly, Siden Top, Anne Vessières, Julie Oble,*

Gérard Jaouen,* and Giovanni Poli*

Sorbonne Universités, UPMC Univ Paris 06, CNRS, Institut Parisien de Chimie Moléculaire (IPCM), UMR 8232, 4, place Jussieu, 75005 Paris, France

Corresponding authors E-mails:

julie.oble@upmc.fr

gerard.jaouen@chimie-paristech.fr

giovanni.poli@upmc.fr 


\section{Synthesis and Analytical data of some intermediates and by-products}

6-Bromobenzo[1,3]dioxole-5-carboxylic acid 3'. To a solution containing $1 \mathrm{~g}$ (4.36 mmol, 1 equiv) of 6-bromopiperonal 3 and 3 drops of a $1 \mathrm{M} \mathrm{H}_{3} \mathrm{PO}_{4}$ solution in $40 \mathrm{~mL}$ of acetone at $10{ }^{\circ} \mathrm{C}$ was added a solution containing $0.53 \mathrm{~g}\left(5.7 \mathrm{mmol}, 1.3\right.$ equiv) of $\mathrm{NaClO}_{2}$ in $100 \mathrm{~mL}$ of water. The yellow solution was warmed to room temperature, and a $35 \% \mathrm{H}_{2} \mathrm{O}_{2}$ solution was added dropwise until the mixture became colorless. The solution was acidified to $\mathrm{pH} 1$ at $0{ }^{\circ} \mathrm{C}$, and the resulting solid was filtered, washed with cold water, and dried to give $0.91 \mathrm{~g}$ (85\%) of 6-bromo-1,3-benzodioxole-5-carboxylic acid as a white solid. ${ }^{1} \mathrm{H}$ NMR (400 MHz, acetone-d $\left.{ }^{6}\right): \delta(\mathrm{ppm}) 7.50(\mathrm{~s}, 1 \mathrm{H}), 7.14(\mathrm{~s}, 1 \mathrm{H}), 6.08(\mathrm{~s}, 2 \mathrm{H})$. These data are in accordance with those reported in the literature. [Erreur ! Signet non défini. ${ }^{]}$

(6-Bromobenzo[1,3]dioxol-5-yl)(ferrocenyl)methanone 3', To a suspension of 6-bromo-1,3benzodioxole-5-carboxylic acid 3' (505.7 mg, $2.06 \mathrm{mmol}, 1$ equiv) in $5 \mathrm{~mL}$ of $\mathrm{CH}_{2} \mathrm{Cl}_{2}$ was added oxalyl chloride $(0.40 \mathrm{~mL}, 5.61 \mathrm{mmol}, 2.75$ equiv). The mixture was stirred at room temperature for 16 $\mathrm{h}$, and then concentrated in vaccuo to remove excess of oxalyl chloride. The residue was dissolved in 5 $\mathrm{mL}$ of $\mathrm{CH}_{2} \mathrm{Cl}_{2}$ and added dropwise on a solution of ferrocene (398.8 mg, $2.14 \mathrm{mmol}, 1$ equiv) and $\mathrm{AlCl}_{3}$ (325.8 mg, $2.45 \mathrm{mmol}, 2$ equiv). After $2 \mathrm{~h}$ at room temperature, the solution was quenched by a saturated aqueous solution of $\mathrm{NH}_{4} \mathrm{Cl}$ and extracted with $\mathrm{CH}_{2} \mathrm{Cl}_{2}$. The organic layer was washed with brine, dried over $\mathrm{MgSO}_{4}$ and concentrated under vacuum. The crude product was purified by flash chromatography on silica (AcOEt/cyclohexane 1:9) to yield $203.6 \mathrm{mg}$ (38\%) of 3". ${ }^{1} \mathrm{H}$ NMR (400 $\left.\mathrm{MHz}, \mathrm{CDCl}_{3}\right) \delta(\mathrm{ppm}) 7.07(\mathrm{~s}, 1 \mathrm{H}), 7.00(\mathrm{~s}, 1 \mathrm{H}), 6.06(\mathrm{~s}, 2 \mathrm{H}), 4.75(\mathrm{t}, J=2.0 \mathrm{~Hz}, 2 \mathrm{H}), 4.58(\mathrm{t}, J=2.0$ $\mathrm{Hz}, 2 \mathrm{H}), 4.28$ (s, 5H). ${ }^{13} \mathrm{C}$ NMR (101 MHz, $\left.\mathrm{CDCl}_{3}\right) \delta$ (ppm) 198.8, 149.5, 146.9, 134.7, 113.7, 111.5, 109.1, 102.4, 78.5, 73.0, 71.4, 70.3. IR (neat, $\mathrm{cm}^{-1}$ ): 1637, 1489, 1445, 1249. Exact mass $\left(\mathrm{C}_{18} \mathrm{H}_{13} \mathrm{O}_{3} \mathrm{FeBr}\right)$ : calculated $434.9303(\mathrm{M}+\mathrm{Na})^{+}$, measured 434.9291.

Benzo[1,3]dioxol-5-yl(pherrocenyl)methanol C'. ${ }^{1} \mathrm{H}$ NMR $\left(300 \mathrm{MHz}, \mathrm{CDCl}_{3}\right) \delta$ (ppm) 6.94-6.93 (m, 1H), 6.90-6.84 (m, 1H), $6.78(\mathrm{~m}, 1 \mathrm{H}), 5.96(\mathrm{~s}, 2 \mathrm{H}), 5.43$ (d, J = 2.4 Hz, 1H), 4.32-4.21 (m, 9H), $2.46(\mathrm{~d}, J=2.8 \mathrm{~Hz}, 1 \mathrm{H}) .{ }^{13} \mathrm{C} \mathrm{NMR}\left(101 \mathrm{MHz}, \mathrm{CDCl}_{3}\right) \delta(\mathrm{ppm}) 147.7,147.0,137.7,119.8,108.1$, 107.1, 101.1, 94.5, 72.1, 69.0, 68.94, 68.7, 68.4, 68.3, 67.6, 65.9. IR (neat, $\mathrm{cm}^{-1}$ ): 3565, 3095, 2925, 1632, 1486. Exact mass $\left(\mathrm{C}_{18} \mathrm{H}_{16} \mathrm{O}_{3} \mathrm{Fe}\right)$ : calculated $336.0443(\mathrm{M})^{+}$, measured 336.0441.

Ethyl 2-acetyl-2-((6-bromobenzo[1,3]dioxol-5-yl)(pherrocenyl)methyl)pent-4-enoate 5. Allylation of the keto-ester 4: To a solution of 4 (300 mg, $0.57 \mathrm{mmol}, 1$ equiv) in $10 \mathrm{~mL}$ of THF was added sodium hydride ( $34 \mathrm{mg}, 0.85 \mathrm{mmol}, 1.5$ equiv). The mixture was stirred at room temperature during 5 min and 15-C-5 crown ether $(0.17 \mathrm{~mL}, 0.85 \mathrm{mmol}, 1.5$ equiv) was added dropwise. After stirring 1 hour at room temperature, allyl iodide $(0.16 \mathrm{~mL}, 1.7 \mathrm{mmol}, 3$ equiv) was added dropwise. The mixture was stirred at reflux during 2 hours until completion monitored by TLC, quenched by a saturated aqueous solution of $\mathrm{NH}_{4} \mathrm{Cl}$ and extracted with $\mathrm{Et}_{2} \mathrm{O}$. The organic layer was washed with brine, dried 
over $\mathrm{MgSO}_{4}$ and concentrated under vacuum. The crude product was purified by flash chromatography on silica $\left(\mathrm{CH}_{2} \mathrm{Cl}_{2} /\right.$ Cyclohexane 6:4) to yield $170 \mathrm{mg}(50 \%)$ of $\mathbf{5}$ as a $50 / 50$ diastereomeric mixture.

Starting from the alcohol C, first essay: To a solution of $4(500 \mathrm{mg}, 1.2 \mathrm{mmol}, 1$ equiv) in $10 \mathrm{~mL}$ of $\mathrm{CH}_{2} \mathrm{Cl}_{2}$ were added the allylated $\beta$-keto-ester 6 (306 mg, $1.8 \mathrm{mmol}, 1.5$ equiv) and TsOH (5 mol\%). The mixture was stirred at reflux during 16 hours, quenched by a saturated aqueous solution of $\mathrm{NaHCO}_{3}$ and extracted with $\mathrm{CH}_{2} \mathrm{Cl}_{2}$. The organic layer was washed with brine, dried over $\mathrm{MgSO}_{4}$ and concentrated under vacuum. The crude product was purified by flash chromatography on silica $\left(\mathrm{CH}_{2} \mathrm{Cl}_{2} /\right.$ Cyclohexane 6:4) to yield $238 \mathrm{mg}(35 \%)$ of 5 as a 50/50 diastereomeric mixture, and $487 \mathrm{mg}$ $(50 \%)$ of the dimerized ether adduct 7.

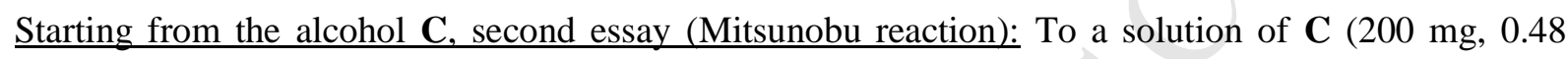
mmol, 1 equiv) in $4 \mathrm{~mL}$ of THF were added 1,1'-(azodicarbonyl)dipiperidine (ADDP) (600 mg, 2.4 mmol, 5 equiv) and $\mathrm{PBu}_{3}(0.6 \mathrm{~mL}, 2.4 \mathrm{mmol}, 5$ equiv). The mixture was stirred at room temperature during $5 \mathrm{~min}$, and the allylated $\beta$-keto-ester $6(410 \mathrm{mg}, 2.4 \mathrm{mmol}, 5$ equiv) was added dropwise. The mixture was stirred at room temperature during 3 days, quenched by a saturated aqueous solution of $\mathrm{NH}_{4} \mathrm{Cl}$ and extracted with $\mathrm{Et}_{2} \mathrm{O}$. The organic layer was washed with brine, dried over $\mathrm{MgSO}_{4}$ and concentrated under vacuum. The crude product was purified by flash chromatography on silica $\left(\mathrm{CH}_{2} \mathrm{Cl}_{2} /\right.$ Cyclohexane 1:1) to yield $94 \mathrm{mg}(35 \%)$ of $\mathbf{5}$ as a $50 / 50$ diastereomeric mixture.

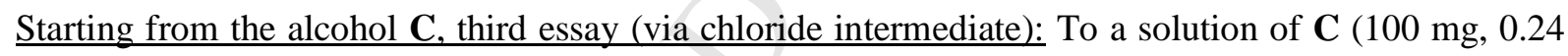
mmol, 1 equiv) in $1 \mathrm{~mL}$ of THF, was added 2,6-lutidine ( $42 \mu \mathrm{L}, 0.36 \mathrm{mmol}, 1.5$ equiv.) followed by a dropwise addition of oxalyl chloride $(25 \mu \mathrm{L}, 0.29 \mathrm{mmol}, 1.2$ equiv). The mixture was stirred at room temperature during $90 \mathrm{~min}$. Separately, ethyl 2-acetylpent-4-enoate $(80 \mathrm{mg}, 0.5 \mathrm{mmol}, 2$ equiv) was added on a suspension of sodium hydride ( $23 \mathrm{mg}, 0.57 \mathrm{mmol}, 2.4$ equiv) in $1 \mathrm{~mL}$ of THF. This solution was cannulated on the solution of $\mathbf{C}$. After overnight at room temperature, the reaction was quenched by a saturated aqueous solution of $\mathrm{NH}_{4} \mathrm{Cl}$ and extracted with $\mathrm{Et}_{2} \mathrm{O}$. The organic layer was washed with a solution of $\mathrm{HCl} 0.1 \mathrm{~N}$, then with brine, dried over $\mathrm{MgSO}_{4}$ and concentrated under vacuum. The crude product was purified by flash chromatography on silica $\left(\mathrm{CH}_{2} \mathrm{Cl}_{2} / \mathrm{Cyclohexane} 1: 1\right)$ to yield $90 \mathrm{mg}(65 \%)$ of 5 as a $50 / 50$ diastereomeric mixture. ${ }^{1} \mathrm{H}$ RMN (400 $\mathrm{MHz}, \mathrm{CDCl}_{3}$, diastereomeric mixture) $\delta(\mathrm{ppm}) 7.13$ (s, 1H, diast. 1), 7.11 (s, 1H, diast. 2), 7.06 (s, 1H, diast. 1), 6.85 (s, 1H, diast. 2), 6.05-6.04 (m, 2H, diast. 1), 6.02-6.01 (m, 2H, diast. 2), 5.65-5.39 (m, 2H, diast. 1 and 2), 5.37 (s, 1H, diast. 1), 5.35 (s, 1H, diast. 2), 4.97-4.86 (m, 4H, diast. 1 and 2), 4.39-3.83 (m, 12H, diast. 1 and 2), 3.94 (s, 5H, diast. 1), 3.92 (s, 5H, diast. 2), 2.57-2.44 (m, 2H, diast. 1), 2.42-2.31 (m, $2 \mathrm{H}$, diast. 2), 2.03 (s, 3H, diast. 1), 1.76 (s, 3H, diast. 2), 1.26 (t, $J=7.2 \mathrm{~Hz}, 3 \mathrm{H}$, diast. 1), 1.10 (t, $J=$ $7.2 \mathrm{~Hz}, 3 \mathrm{H}$, diast. 2). ${ }^{13} \mathrm{C} \mathrm{NMR}\left(101 \mathrm{MHz}, \mathrm{CDCl}_{3}\right.$, diastereomeric mixture) $\delta$ (ppm) 206.6 (diast. 1), 204.6 (diast. 2), 171.9 (diast. 1), 171.7 (diast. 2), 147.4, 147.3, 147.2, 147.1 (diast. 1 and 2), 133.8 
(diast. 1), 133.1 (diast. 2), 132.8 (diast. 1), 132.2 (diast. 2), 118.8 (diast. 1), 118.0 (diast. 2), 117.5 (diast. 1 and 2), 112.8 (diast. 1 and 2), 110.1 (diast. 1), 101.0 (diast. 2), 102.1 (diast. 1), 102.0 (diast. 2), 88.1 (diast. 1), 87.9 (diast. 2), 71.4, 69.6, 69.0, 68.8, 68.4, 68.1, 67.7, 67.3 (diast. 1 and 2), 69.6 (diast. 1), 69.5 (diast. 2), 69.0 (diast. 1), 68.8 (diast. 2), 61.4 (diast. 1), 61.3 (diast. 2), 47.9 (diast. 1), 47.2 (diast. 2), 39.5 (diast. 1), 39.3 (diast. 2), 31.7 (diast. 1), 30.3 (diast. 2), 14.2 (diast. 1), 13.8 (diast. 2). IR (neat, $\left.\mathrm{cm}^{-1}\right)$ : 3079, 1730, 1700, 1638, 1503, 1478. Exact mass $\left(\mathrm{C}_{27} \mathrm{H}_{27} \mathrm{BrFeO}_{5}\right)$ : calculated $589.0285(\mathrm{M}+\mathrm{Na})^{+}$, measured 589.0301.

6,6'-(Oxybis(pherrocenylmethylene))bis(5-bromobenzo[1,3]dioxole) 7. ${ }^{1} \mathrm{H}$ RMN $(300 \mathrm{MHz}$, $\left.\mathrm{CDCl}_{3}\right) \delta(\mathrm{ppm}) 7.11(\mathrm{~s}, 2 \mathrm{H}), 6.93(\mathrm{~s}, 2 \mathrm{H}), 5.93(\mathrm{~d}, J=1.3 \mathrm{~Hz}, 2 \mathrm{H}), 5.91(\mathrm{~d}, J=1.3 \mathrm{~Hz}, 2 \mathrm{H}), 5.45$ (s, 2H), 4.24 (s, 2H), 4.07-3.93 (m, 16H). $\left.{ }^{13} \mathrm{C} \mathrm{NMR} \mathrm{(101} \mathrm{MHz,} \mathrm{CDCl}_{3}\right) \delta$ (ppm) 148.1, 147. 9, 135.1, 114.5, 112.2, 108.6, 102.0, 90.7, 75.8, 69.0, 68.0, 67.8, 67.1, 66.2. IR (neat, $\mathrm{cm}^{-1}$ ): 3095, 2894, 1612, 1502, 1234. Exact mass $\left(\mathrm{C}_{36} \mathrm{H}_{28} \mathrm{Br}_{2} \mathrm{Fe}_{2} \mathrm{O}_{5}\right)$ : calculated $832.8896(\mathrm{M}+\mathrm{Na})^{+}$, measured 832.8875 . 
O-ferrocenylpodophyllotoxin (1).

mbe228

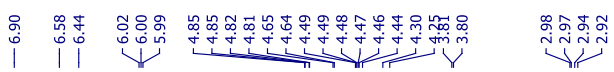

\begin{tabular}{|lc|}
\hline \multicolumn{1}{|c}{ Parameter } & Value \\
1 Solvent & CDCl3 \\
2 Temperature & 300.0 \\
3 Pulse Sequence & 2g30 \\
4 Spectrometer Frequency & 400.13 \\
5 Nucleus & $1 \mathrm{H}$ \\
\hline \multicolumn{2}{|c}{} \\
\hline
\end{tabular}

$a^{2} 0^{\circ}$

sxis.

Nes

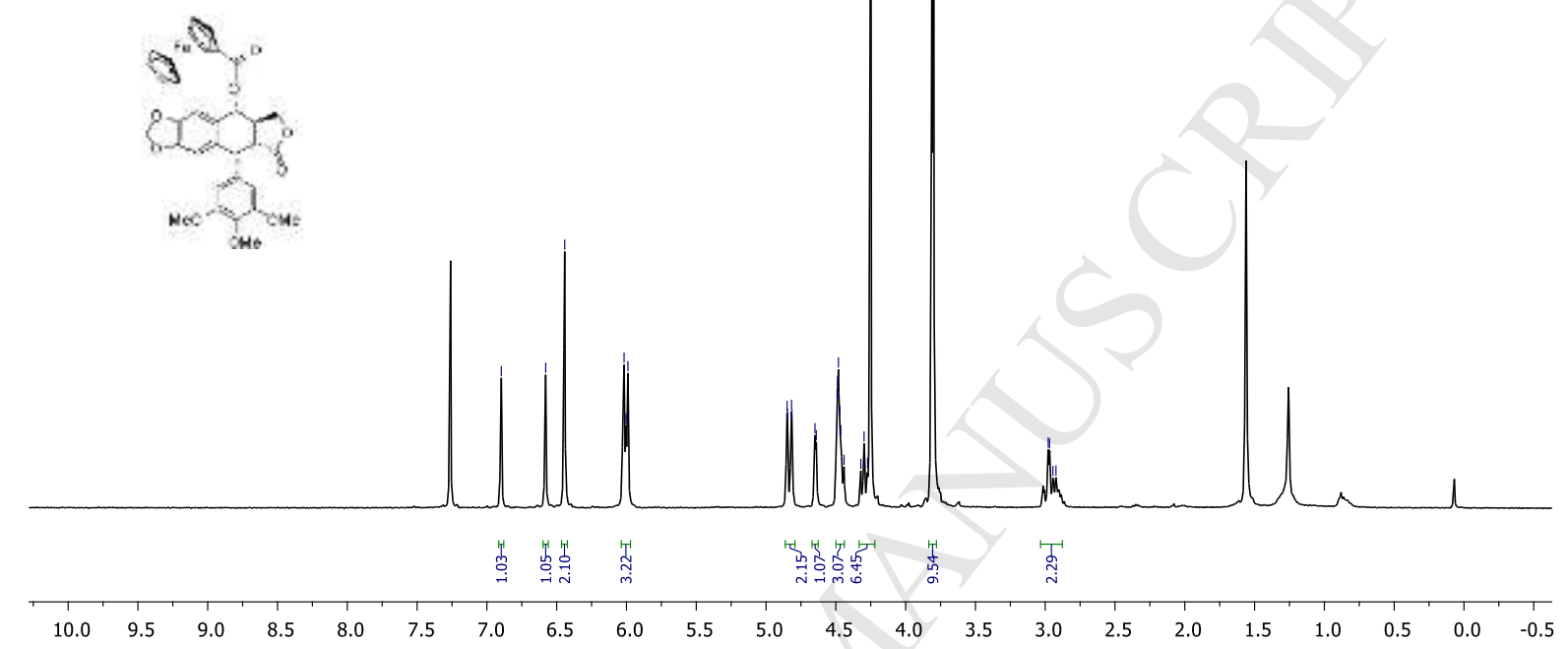

mbe228

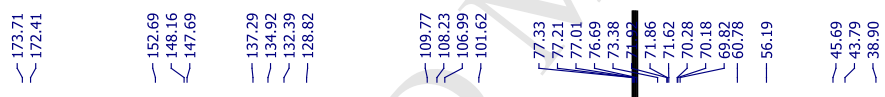

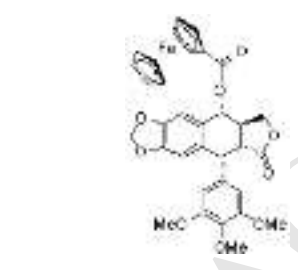

\begin{tabular}{|lr|}
\hline \multicolumn{1}{|c}{ Parameter } & Value \\
1 Solvent & CDCl3 \\
2 Temperature & 300.0 \\
3 Pulse Sequence & 29pg30 \\
4 Spectrometer Frequency & 100.61 \\
5 5 Nucleus & $13 \mathrm{C}$ \\
\hline
\end{tabular}

\begin{tabular}{|c|}
\hline lue \\
.0 \\
\hline 30 \\
\hline
\end{tabular}

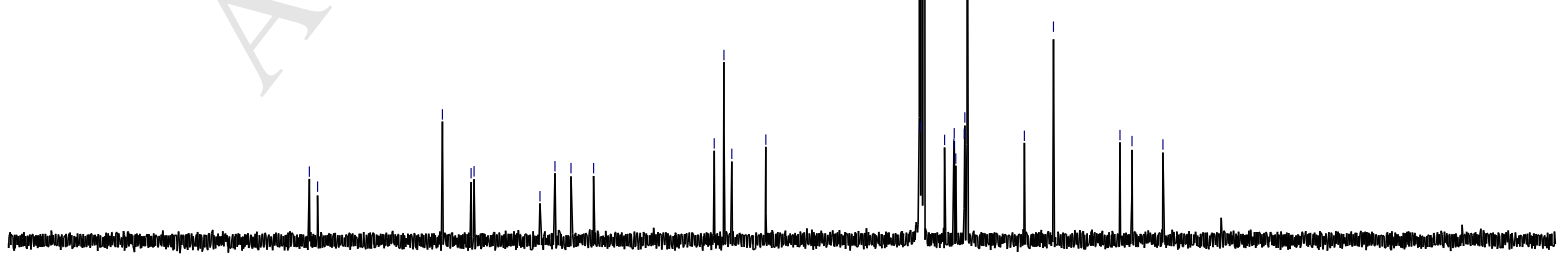

$\begin{array}{lllllllllllllllllllllllllllllllllll}220 & 210 & 200 & 190 & 180 & 170 & 160 & 150 & 140 & 130 & 120 & 110 & 100 & 90 & 80 & 70 & 60 & 50 & 40 & 30 & 20 & 10 & 0 & -10 & -20\end{array}$ 
6-Bromobenzo[1,3]dioxole-5-carboxylic acid (3').

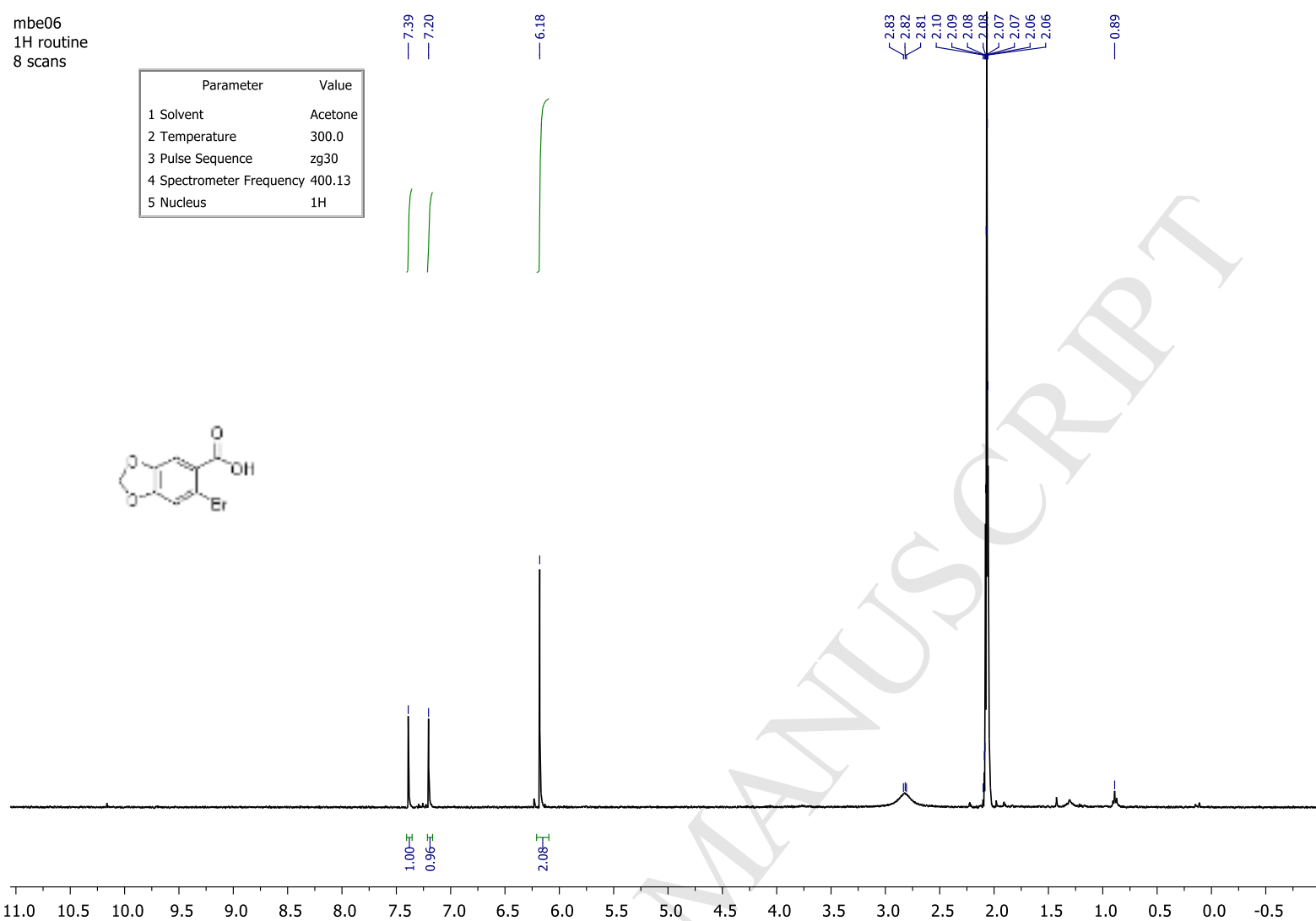


(6-Bromobenzo[1,3]dioxol-5-yl)(ferrocenyl)methanone (3')).

mbe07

$1 \mathrm{H}$ routine

8 scans

\begin{tabular}{|c|c|}
\hline Parameter & Value \\
\hline 1 Solvent & $\mathrm{CDCl} 3$ \\
\hline 2 Temperature & 300.0 \\
\hline 3 Pulse Sequence & 2930 \\
\hline \multicolumn{2}{|c|}{4 Spectrometer Frequency 400.1} \\
\hline 5 Nucleus & $1 \mathrm{H}$ \\
\hline
\end{tabular}

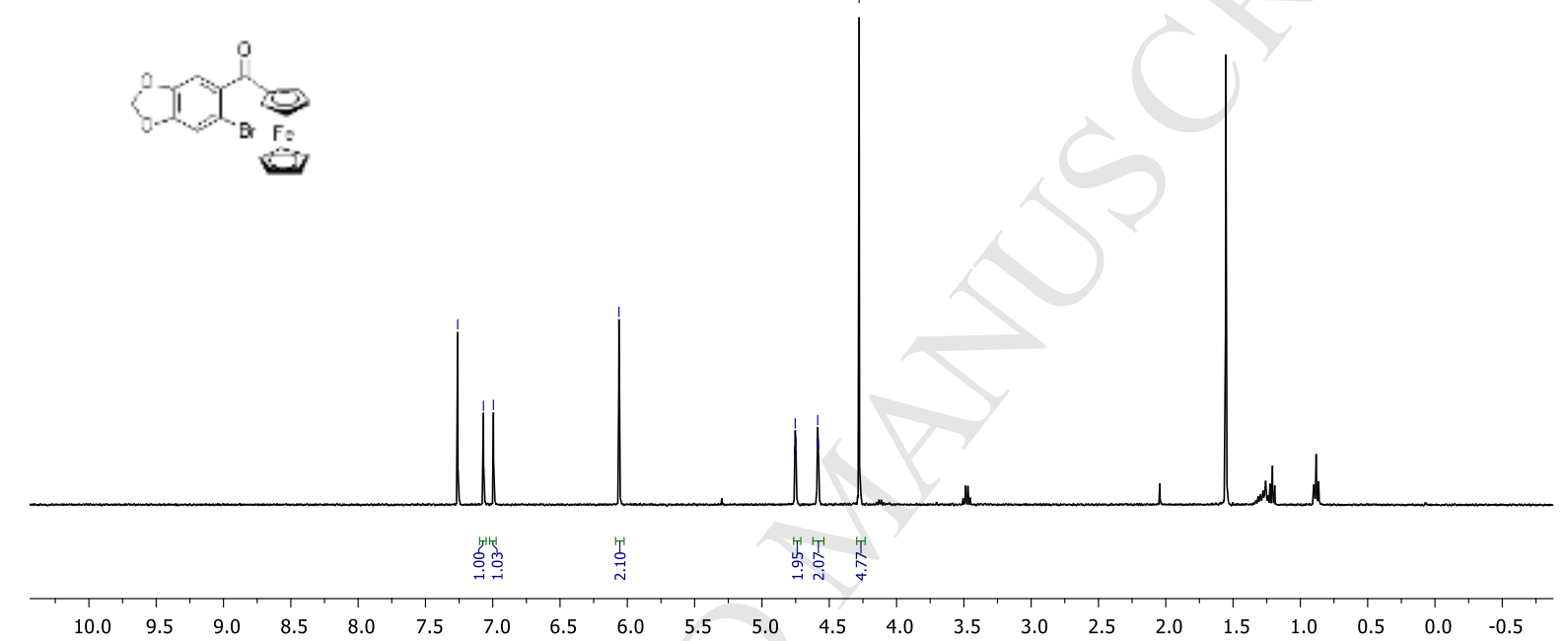

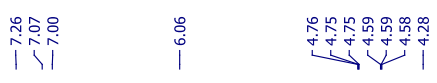

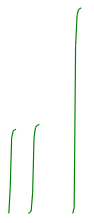

MBE07

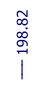

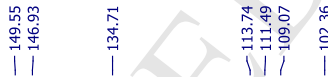

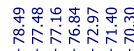

(1)

\begin{tabular}{lr}
\multicolumn{1}{c}{ Parameter } & Value \\
1 Solvent & CDCl3 \\
2 Temperature & 300.0 \\
3 Pulse Sequence & zgpg30 \\
4 Spectrometer Frequency & 100.61 \\
5 Nucleus & $13 \mathrm{C}$
\end{tabular}

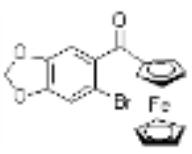

$\begin{array}{lllllllllllll}210 & 200 & 190 & 180 & 170 & 160 & 150 & 140 & 130 & 120 & 110 & 100 & 90\end{array}$

$\begin{array}{lllllllll}70 & 60 & 50 & 40 & 30 & 20 & 10 & 0 & -10\end{array}$ 
(6-Bromobenzo[1,3]dioxol-5-yl)(pherrocenyl)methanol (C).

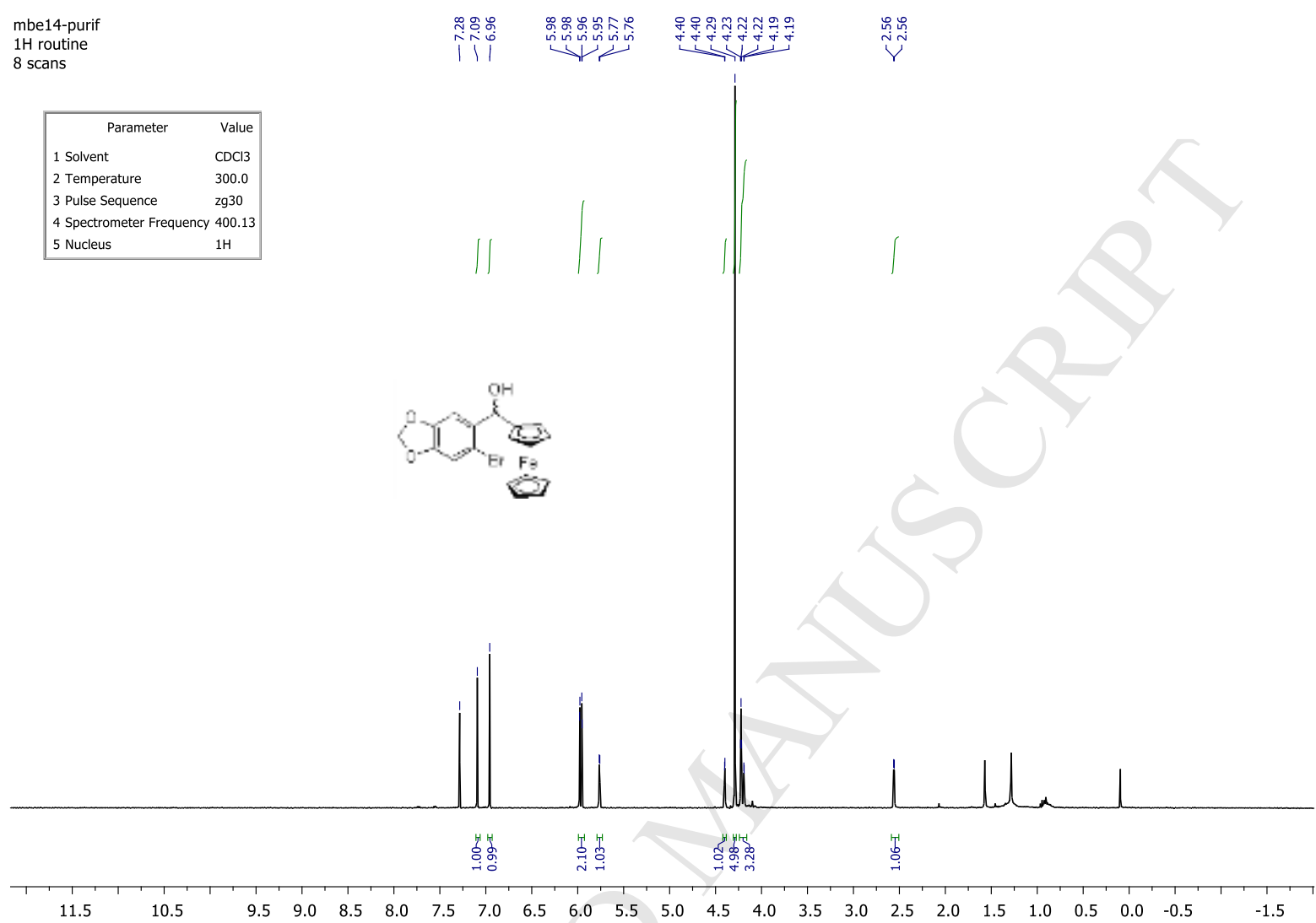

MBE14-purif

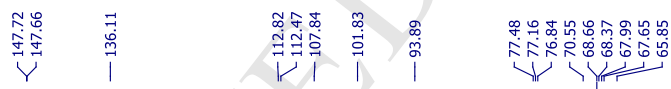

\begin{tabular}{|lc|}
\hline \multicolumn{1}{|c}{ Parameter } & Value \\
1 Solvent & $\mathrm{CDCl} 3$ \\
2 Temperature & 300.0 \\
3 Pulse Sequence & $\mathrm{zgpg} 30$ \\
4 Spectrometer Frequency & 100.61 \\
5 Nucleus & $13 \mathrm{C}$ \\
\hline
\end{tabular}

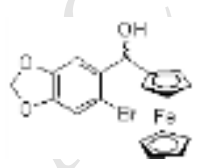

$\begin{array}{llllllllll}190 & 180 & 170 & 160 & 150 & 140 & 130 & 120 & 110 & 100\end{array}$

$\begin{array}{lllll}90 & 80 & 70 & 60 & 50\end{array}$

40

3020 
Benzo[1,3]dioxol-5-yl(pherrocenyl)methanol (C').

mbe10f2

Y

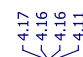

$\stackrel{\text { I. }}{\sim}$

\begin{tabular}{|lc|}
\hline \multicolumn{1}{|c}{ Parameter } & Value \\
1 Solvent & CDCl3 \\
2 Temperature & 300.0 \\
3 Pulse Sequence & $\mathrm{zg} 30$ \\
4 Spectrometer Frequency & 300.16 \\
5 Nucleus & $1 \mathrm{H}$ \\
\hline
\end{tabular}

$\int_{03}^{2+3}$
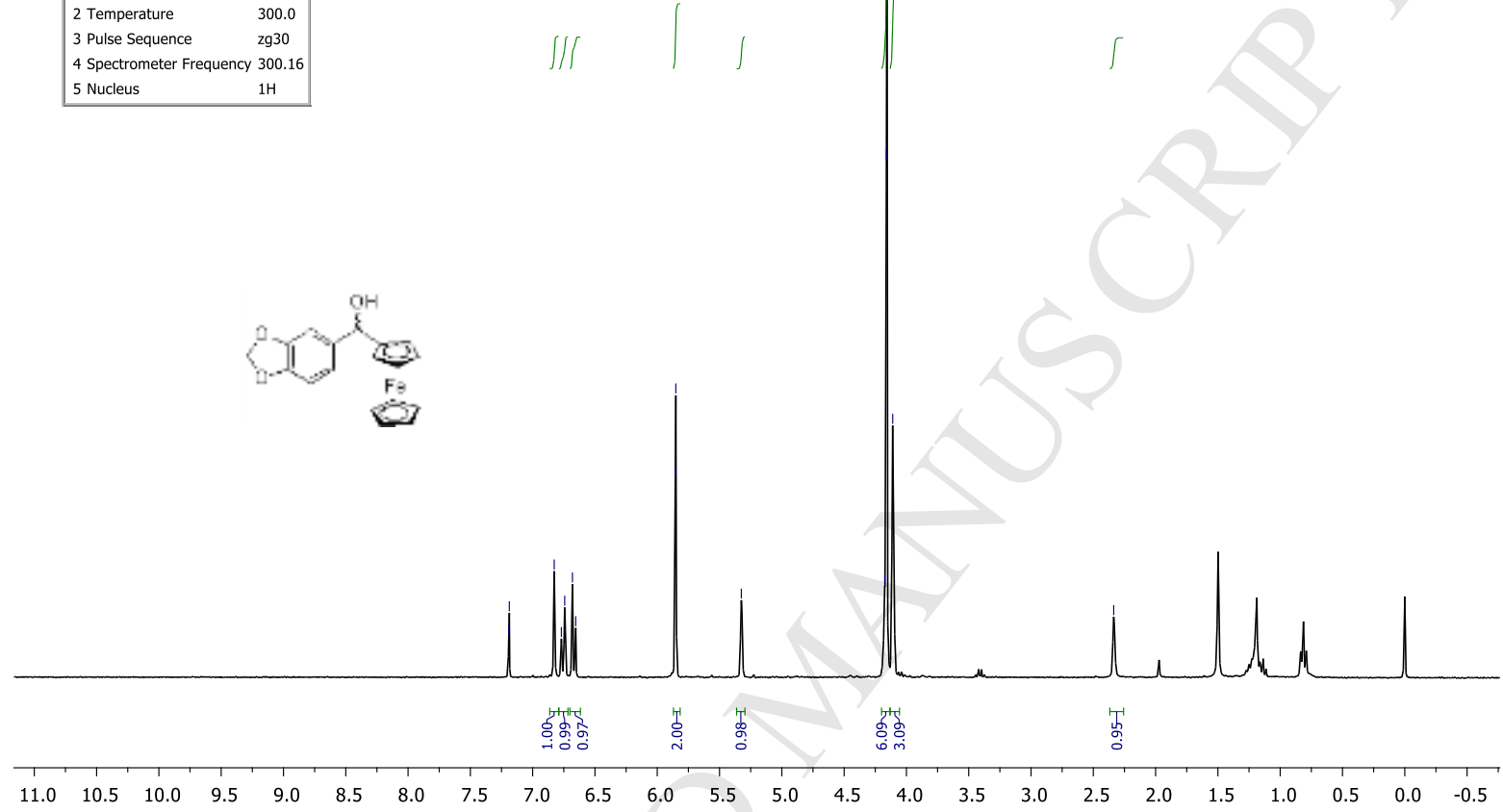

GP-FR146-13C

V)

\begin{tabular}{|lr|}
\hline \multicolumn{1}{|c}{ Parameter } & Value \\
1 Solvent & CDCl3 \\
2 Temperature & 300.0 \\
3 Pulse Sequence & ggpg30 \\
4 Spectrometer Frequency & 100.61 \\
5 Nucleus & $13 \mathrm{C}$ \\
\hline
\end{tabular}
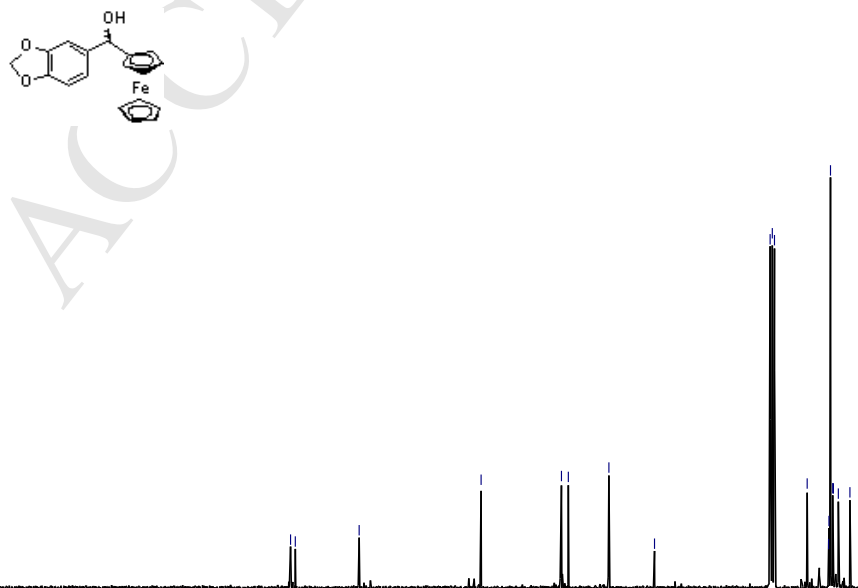

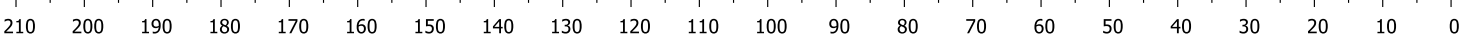


Ethyl 2-((6-bromobenzo[1,3]dioxol-5-yl)(pherrocenyl)methyl)-3-oxobutanoate (4).

MBE41

\begin{tabular}{|ll|}
\hline \multicolumn{1}{|c|}{ Parameter } & \multicolumn{1}{c|}{ Value } \\
1 Solvent & $\mathrm{CDCl3}$ \\
2 Temperature & 300.0 \\
3 Pulse Sequence & $\mathrm{zg} 30$ \\
4 Spectrometer Frequency & 300.16 \\
5 Nucleus & $1 \mathrm{H}$ \\
\hline
\end{tabular}

ilif

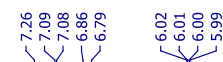

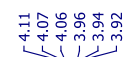

年

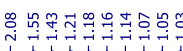

1 年
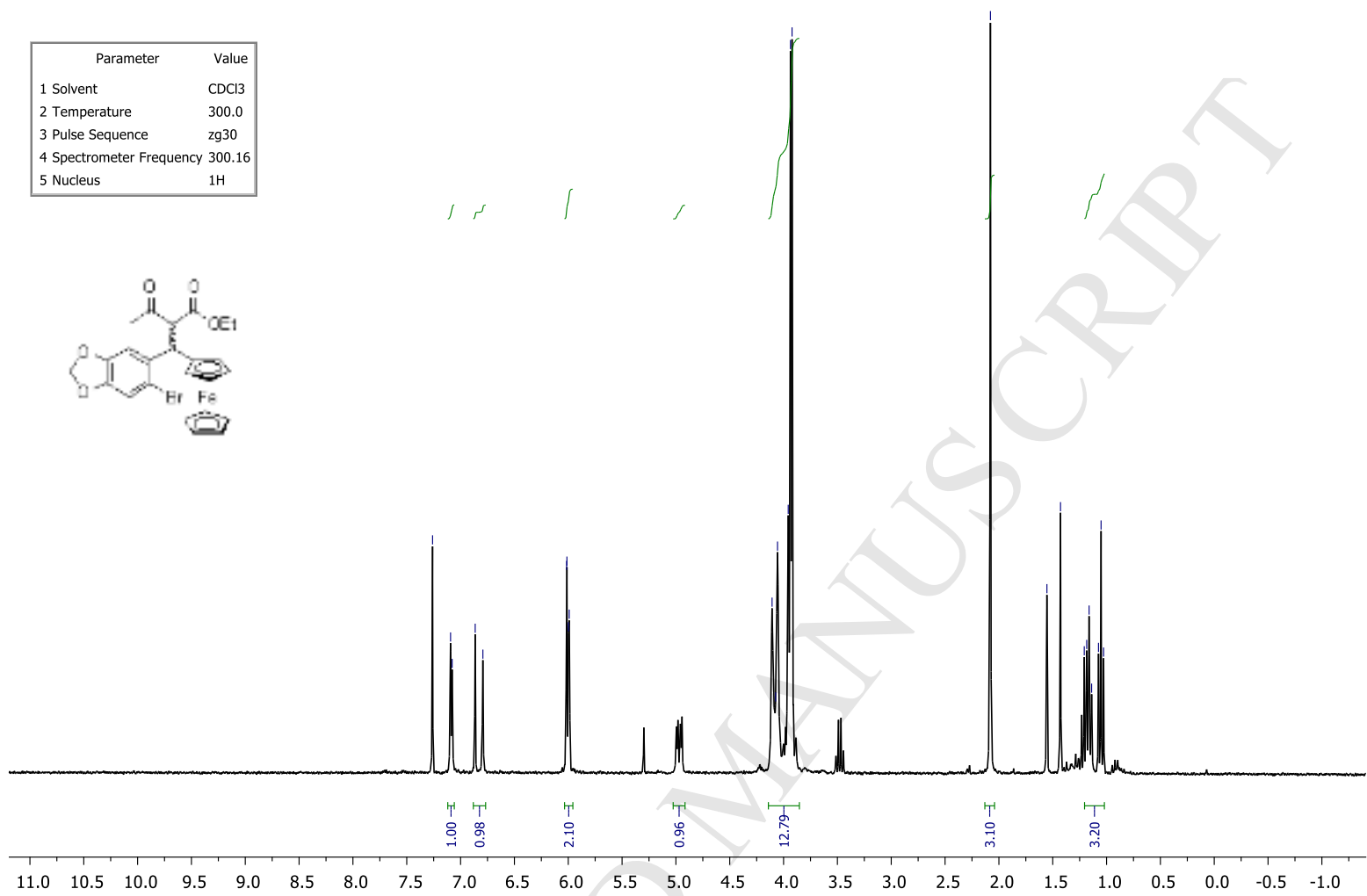

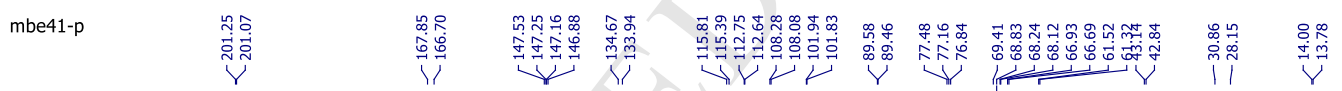

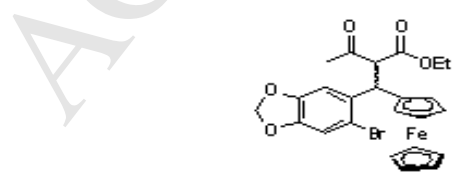

Temperature $\quad 300.0$

$\begin{array}{lr}3 \text { Pulse Sequencer } & \text { zgpg30 } \\ 4 \text { Spectrometer Frequency } 100.61\end{array}$

5 Nucleus $\quad 13 \mathrm{C}$

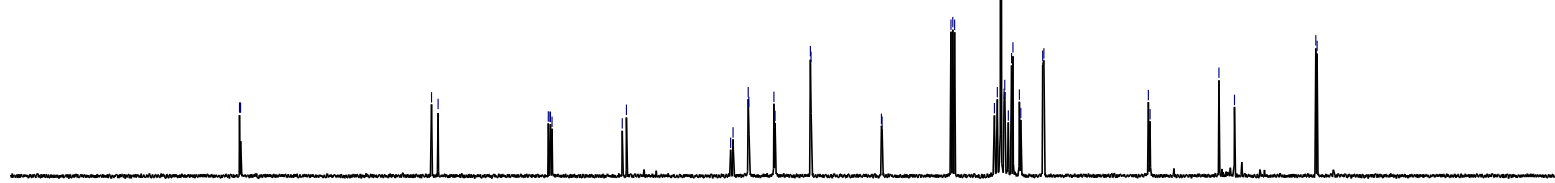

$\begin{array}{llllllllllllllllllllllllllllllllllllllllllll}240 & 230 & 220 & 210 & 200 & 190 & 180 & 170 & 160 & 150 & 140 & 130 & 120 & 110 & 100 & 90 & 80 & 70 & 60 & 50 & 40 & 30 & 20 & 10 & 0 & -10 & -20\end{array}$ 
Ethyl 2-acetyl-2-((6-bromobenzo[1,3]dioxol-5-yl)(pherrocenyl)methyl)pent-4-enoate (5).

mbe131UP

8 scans

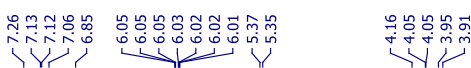



\begin{tabular}{|lc|}
\hline \multicolumn{1}{|c}{ Parameter } & Valu \\
1 Solvent & $\mathrm{CDCl}$ \\
2 Temperature & 300.0 \\
3 Pulse Sequence & $\mathrm{zg} 30$ \\
4 Spectrometer Frequency & 400.13 \\
5 Nucleus & $1 \mathrm{H}$ \\
\hline
\end{tabular}

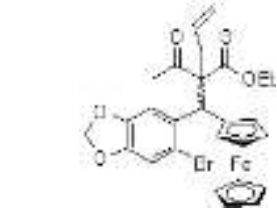

\begin{tabular}{l} 
Value \\
CDCl3 \\
00.0 \\
2930 \\
400.13 \\
\hline 4
\end{tabular}
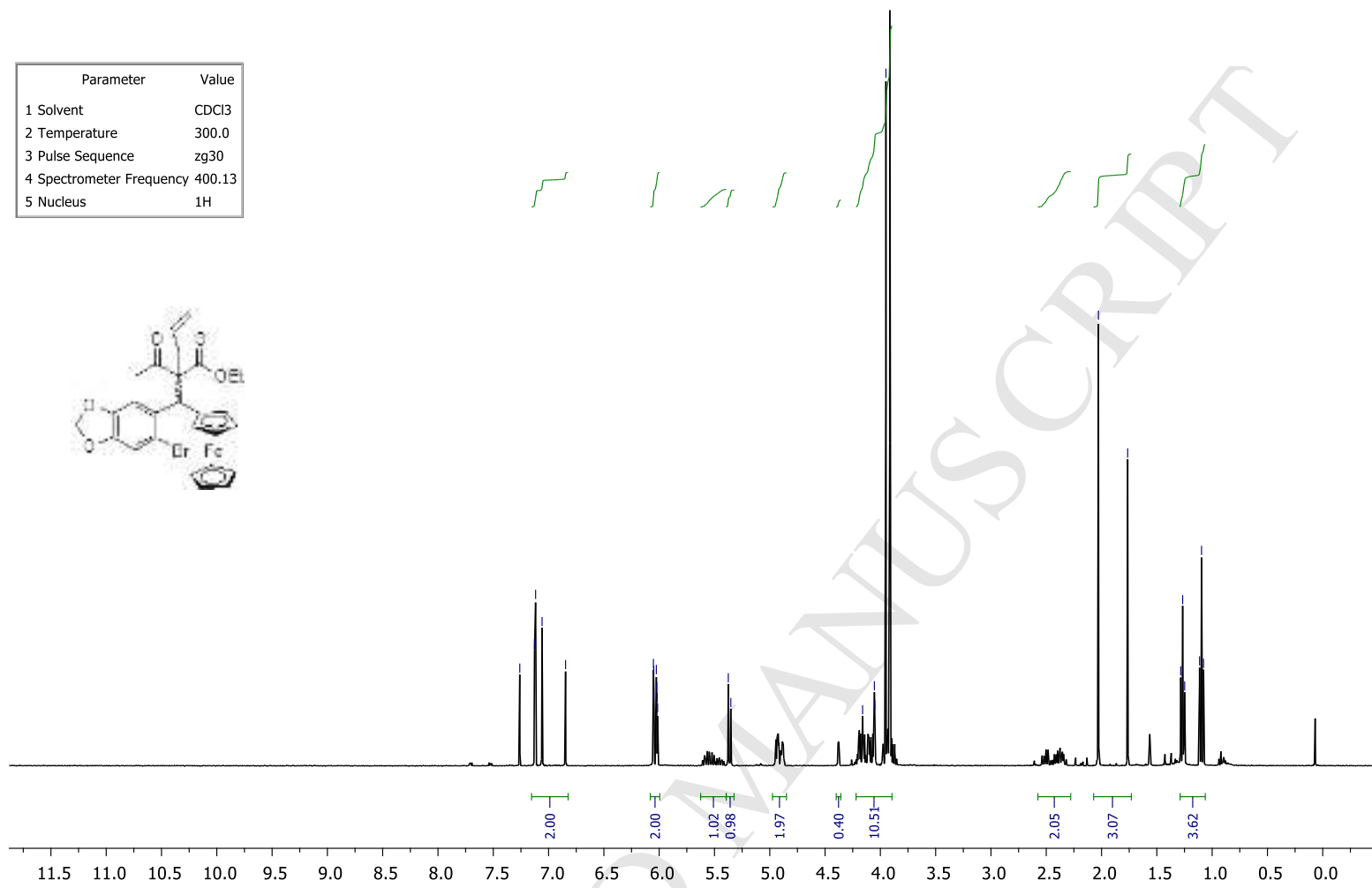

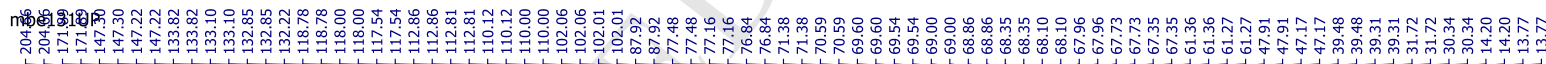

\begin{tabular}{|lc|}
\hline \multicolumn{1}{|c|}{ Parameter } & Value \\
1 Solvent & $\mathrm{CDCl} 3$ \\
2 Temperature & 300.0 \\
3 Pulse Sequence & ggpg 30 \\
4 Spectrometer Frequency & 100.61 \\
5 Nucleus & $13 \mathrm{C}$ \\
\hline
\end{tabular}

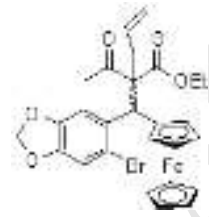

$13 \mathrm{C}$

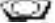


6,6'-(Oxybis(pherrocenylmethylene))bis(5-bromobenzo[1,3]dioxole) (7).

GP-FR147-tes

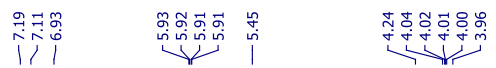

\begin{tabular}{|ll|}
\hline \multicolumn{1}{|c|}{ Parameter } & Value \\
1 Solvent & CDCl3 \\
2 Temperature & 300.0 \\
3 Pulse Sequence & g930 \\
4 Spectrometer Frequency & 300.16 \\
5 Nucleus & $1 \mathrm{H}$ \\
\hline
\end{tabular}
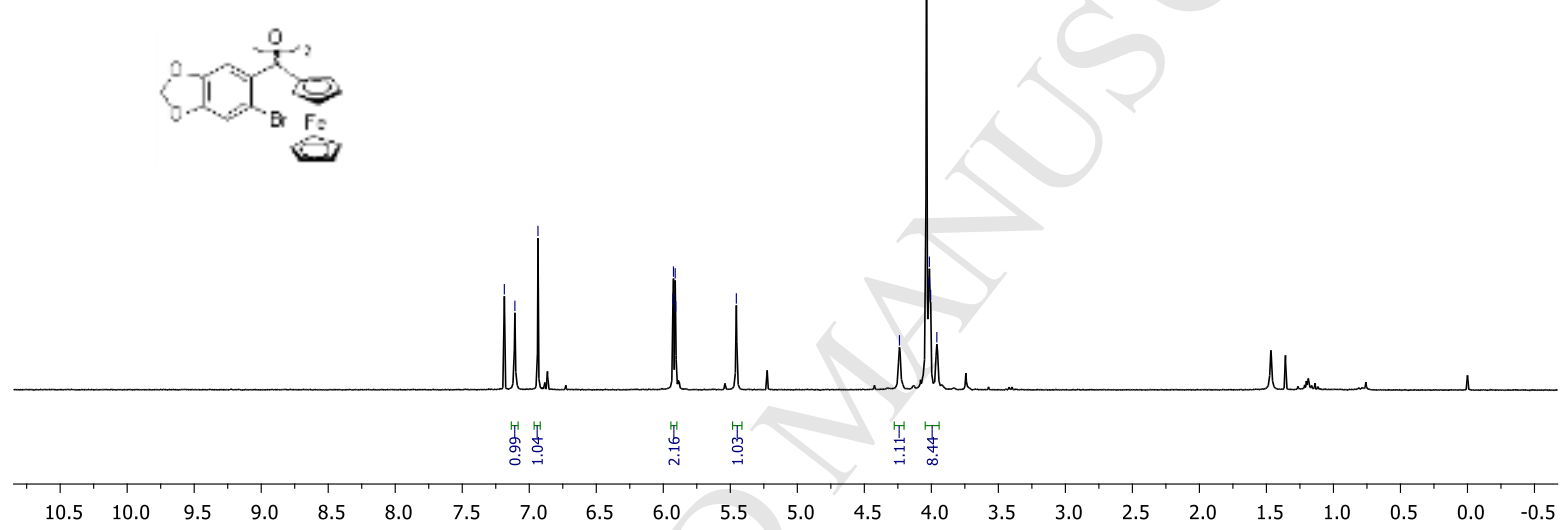

GP-FR147-13C

\begin{tabular}{|ll|}
\hline \multicolumn{1}{|c}{ Parameter } & \multicolumn{1}{c|}{ Value } \\
1 Solvent & CDCl3 \\
2 Temperature & 300.0 \\
3 Pulse Sequence & zgpg 30 \\
4 Spectrometer & 100.61 \\
$\begin{array}{l}\text { Frequency } \\
\text { 5 Nucleus }\end{array}$ & $13 \mathrm{C}$ \\
\hline
\end{tabular}

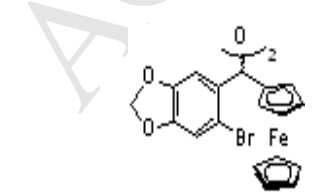

$\begin{array}{llllllllllllllllllllllll}220 & 210 & 200 & 190 & 180 & 170 & 160 & 150 & 140 & 130 & 120 & 110 & 100 & 90 & 80 & 70 & 60 & 50 & 40 & 30 & 20 & 10 & 0 & -10\end{array}$ 
Ethyl 6-acetyl-8-methylene-5-pherrocenyl-5,6,7,8-tetrahydronaphtho[2,3- $d][1,3]$ dioxole-6carboxylate (8).

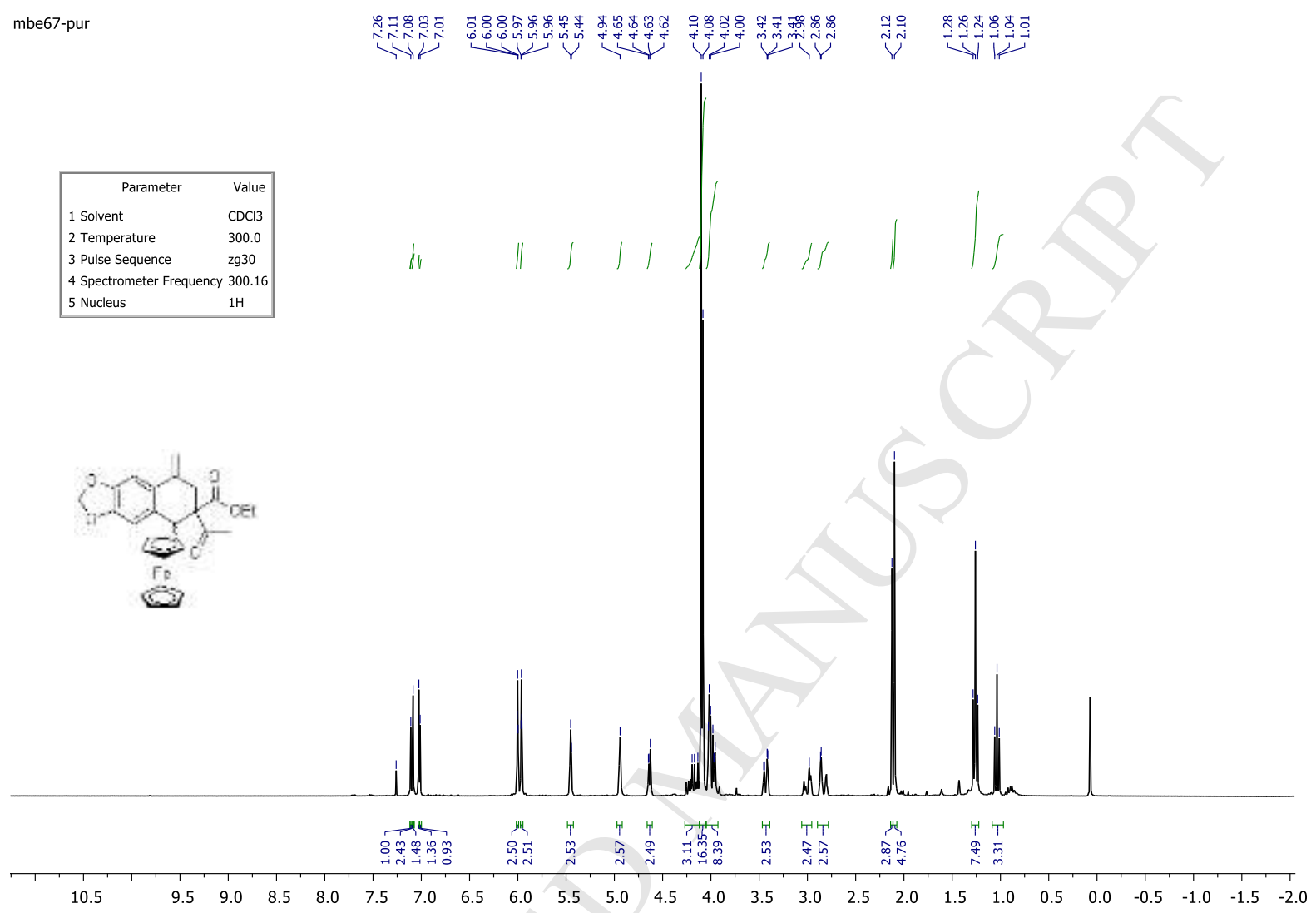




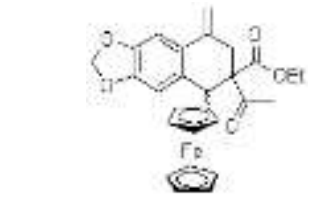

Ethyl 8-methylene-5-pherrocenyl-5,6,7,8-tetrahydronaphtho[2,3-d][1,3]dioxole-6-carboxylate (9).

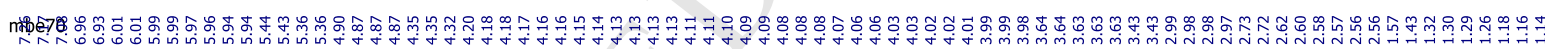

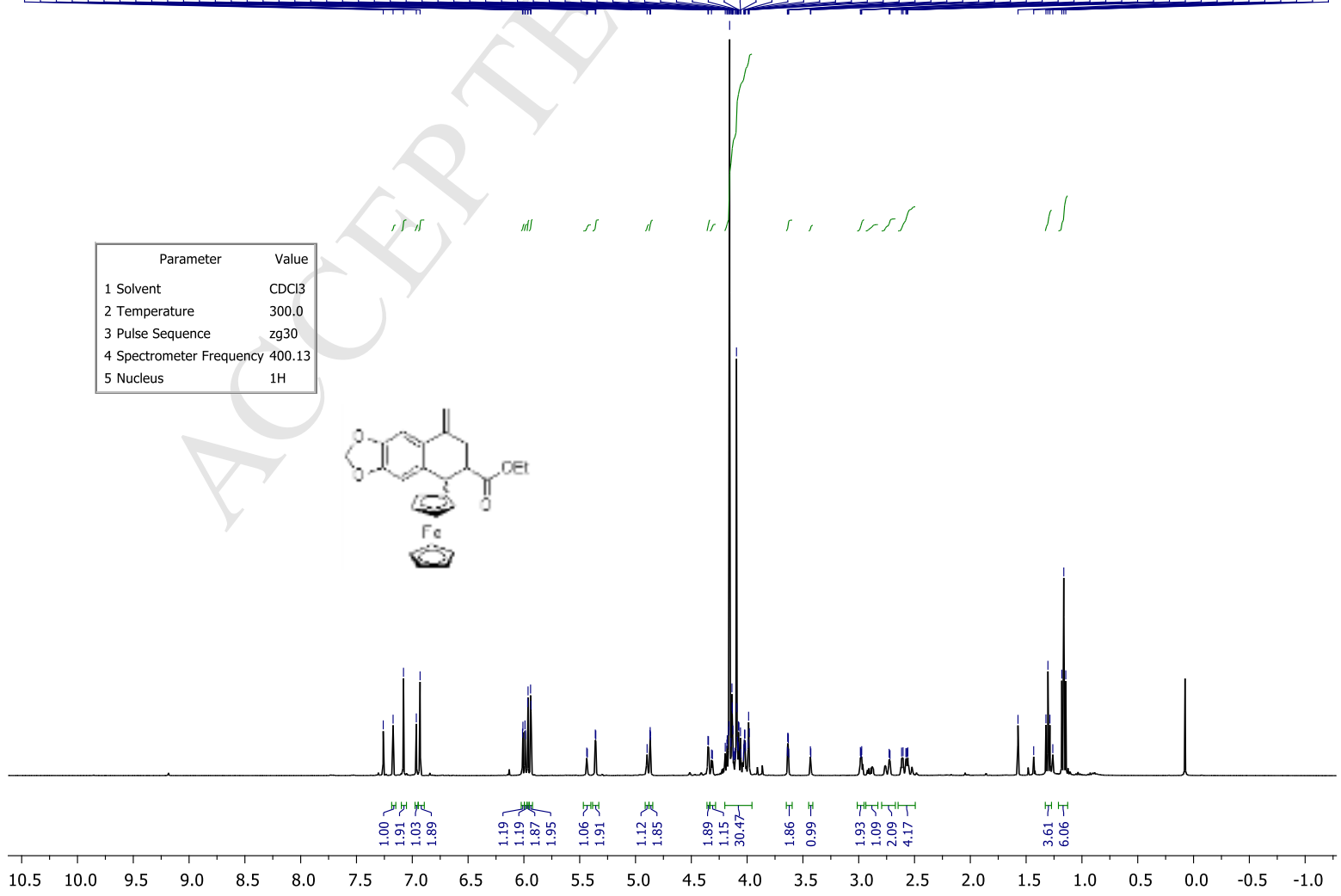




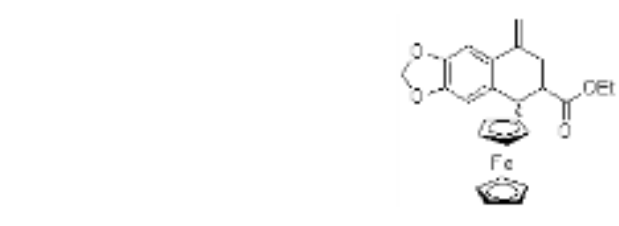

Ethyl 8-oxo-5-pherrocenyl-5,6,7,8-tetrahydronaphtho[2,3-d][1,3]dioxole-6-carboxylate (A).

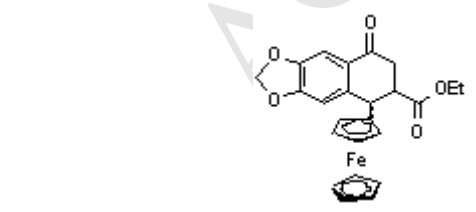

îi

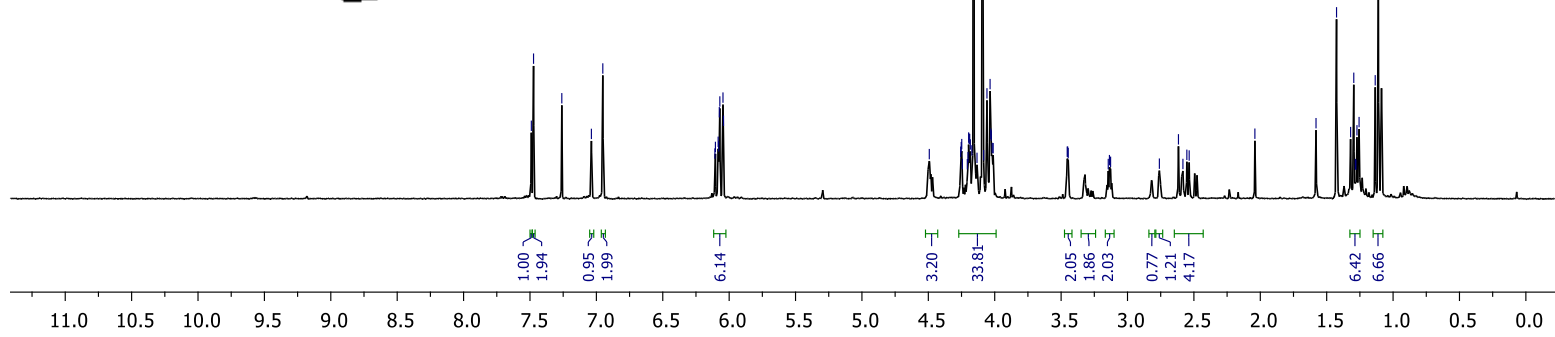


MBE84PUR

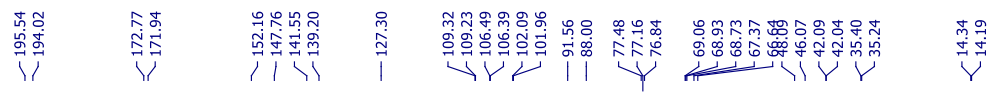

\begin{tabular}{|lc|}
\hline \multicolumn{1}{|c|}{ Parameter } & \multicolumn{1}{c|}{ Value } \\
1 Solvent & $\mathrm{CDCl} 3$ \\
2 Temperature & 300.0 \\
3 Pulse Sequence & $\mathrm{zgpg} 30$ \\
4 Spectrometer Frequency & 100.61 \\
5 Nucleus & $13 \mathrm{C}$ \\
\hline
\end{tabular}
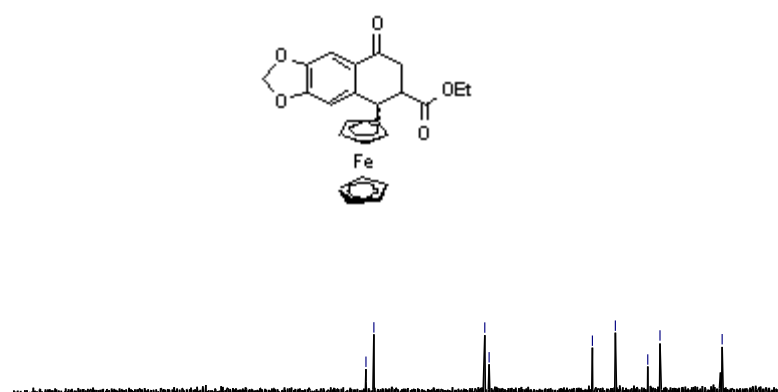

$\begin{array}{lllllllllllll}90 & 80 & 70 & 60 & 50 & 40 & 30 & 20 & 10 & 0 & -10 & -20 & -30\end{array}$

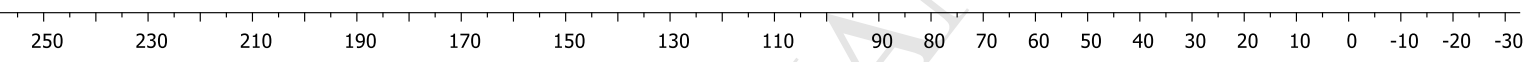


Ethyl 8-hydroxy-5-pherrocenyl-5,6,7,8-tetrahydronaphtho[2,3-d][1,3]dioxole-6-carboxylate 2 (R $=\mathrm{Et}$ ) Major diastereoisomer

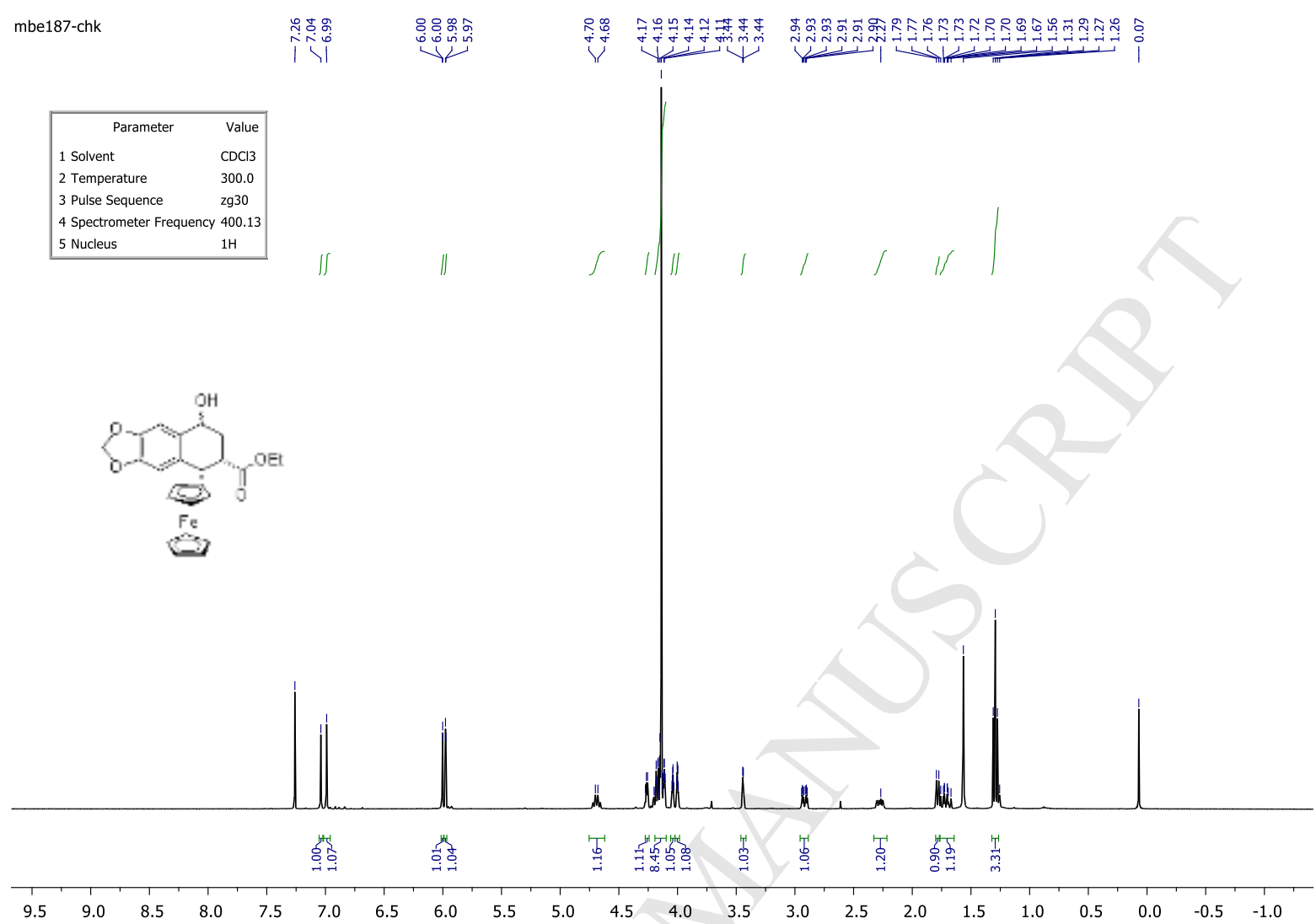

mbe187-f2

\begin{tabular}{|lc|}
\hline \multicolumn{1}{|c|}{ Parameter } & Value \\
1 Solvent & CDC13 \\
2 Temperature & 300.0 \\
3 Pulse Sequence & jmod \\
4 Spectrometer Frequency & 100.61 \\
5 Nucleus & $13 \mathrm{C}$ \\
\hline
\end{tabular}
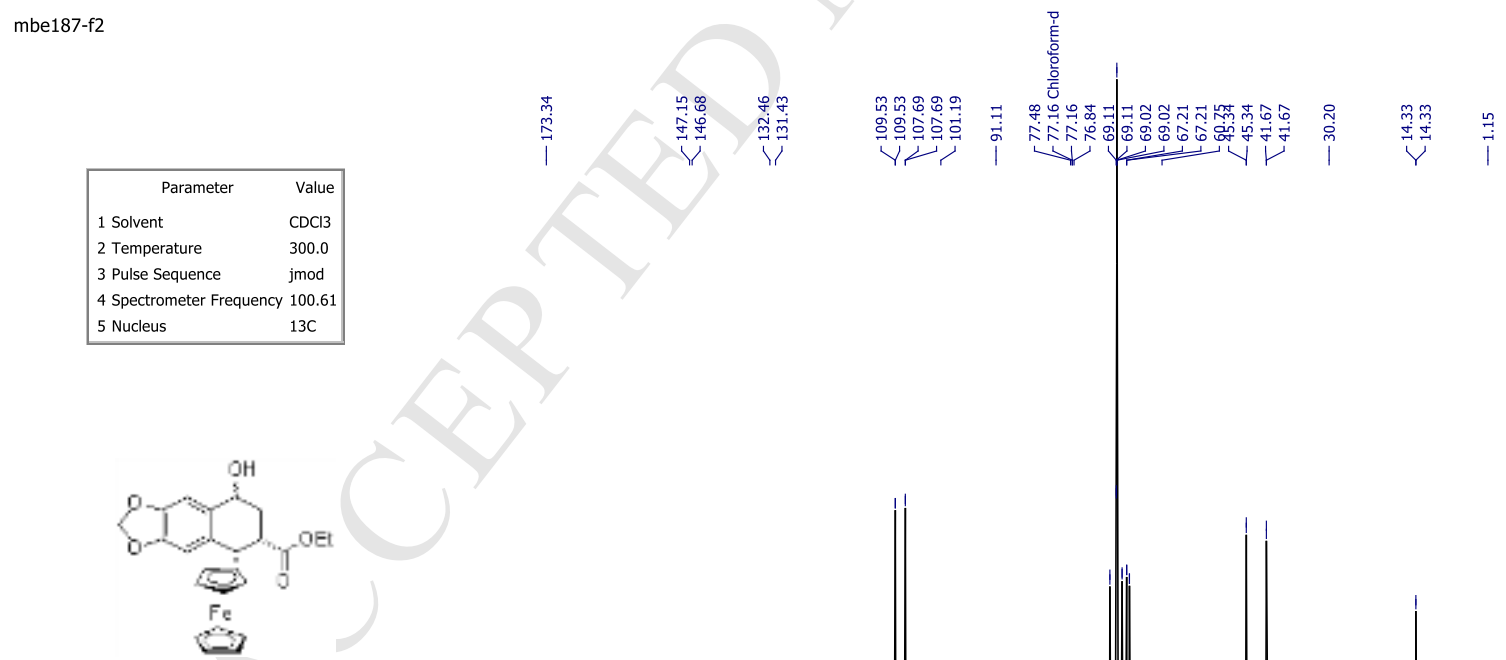

$\begin{array}{lllllllllllllllllllllllllllllllllllllllllllllll}270 & 260 & 250 & 240 & 230 & 220 & 210 & 200 & 190 & 180 & 170 & 160 & 150 & 140 & 130 & 120 & 110 & 100 & 90 & 80 & 70 & 60 & 50 & 40 & 30 & 20 & 10 & 0 & -10\end{array}$ 
Ethyl 8-hydroxy-5-pherrocenyl-5,6,7,8-tetrahydronaphtho[2,3-d][1,3]dioxole-6-carboxylate 2 (R $=\mathrm{Et})$ minor diastereoisomer

mbe187-f1

i

\begin{tabular}{|ll|}
\hline \multicolumn{1}{|c|}{ Parameter } & Value \\
1 Solvent & CDCl3 \\
2 Temperature & 300.0 \\
3 Pulse Sequence & $\mathrm{zg} 30$ \\
4 Spectrometer Frequency & 400.13 \\
5 Nucleus & $1 \mathrm{H}$ \\
\hline
\end{tabular}
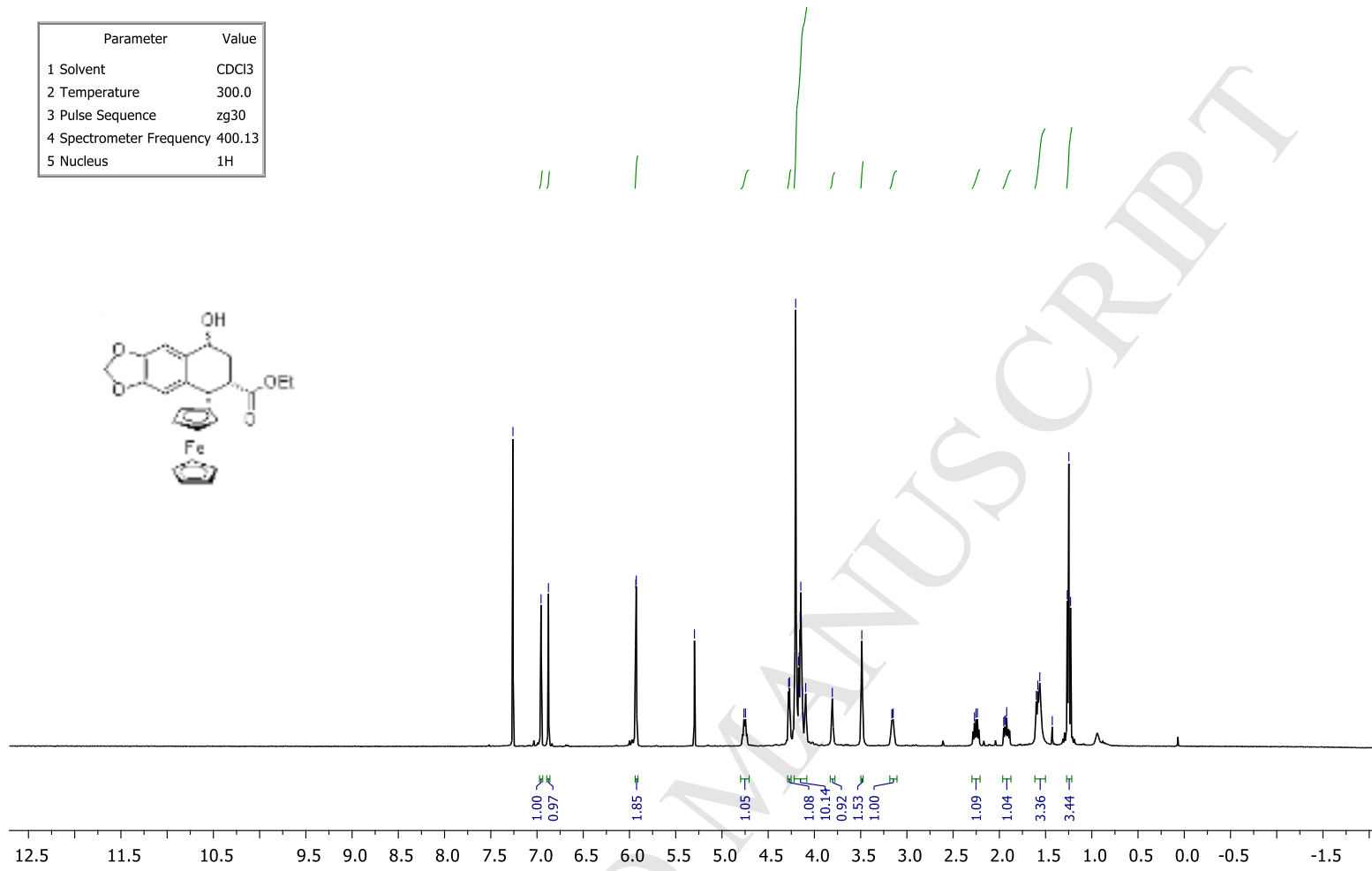

\begin{tabular}{|lc|}
\hline nbe187-f $\mathrm{f}$ arameter & Value \\
1 Solvent & $\mathrm{CDCl} 3$ \\
2 Temperature & 300.0 \\
3 Pulse Sequence & jmod \\
4 Spectrometer Frequency & 100.61 \\
5 Nucleus & $13 \mathrm{C}$ \\
\hline
\end{tabular}
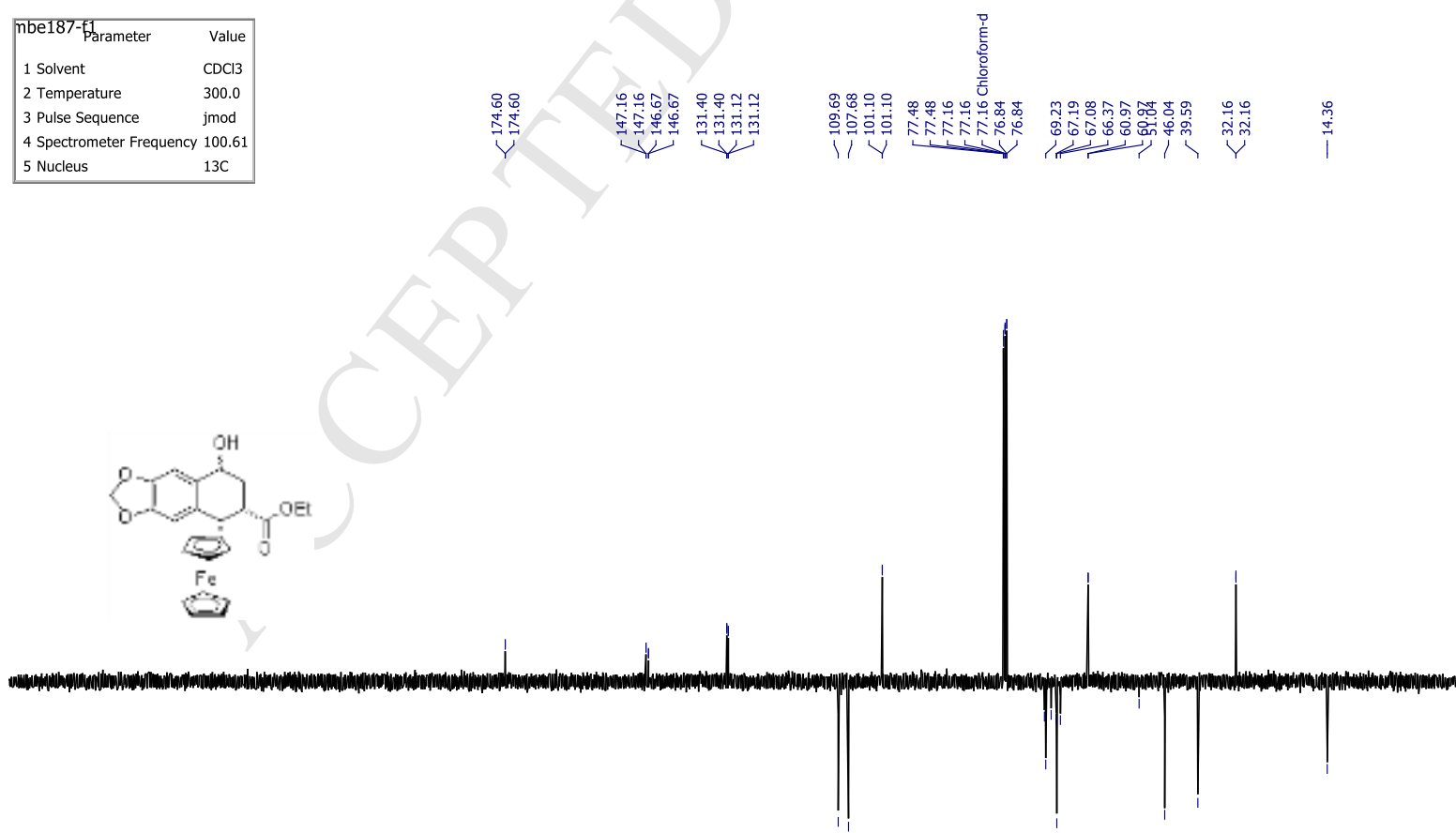

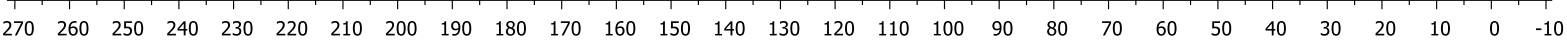

